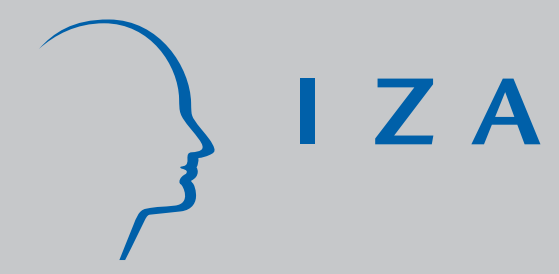

IZA DP No. 156

Language Proficiency and Labour Market Performance of Immigrants in the UK

Christian Dustmann

Francesca Fabbri

May 2000 


\title{
Language Proficiency and Labour Market Performance of Immigrants in the UK
}

\author{
Christian Dustmann \\ University College London, Department of Economics and Institute for Fiscal Studies \\ and IZA, Bonn \\ Francesca Fabbri \\ University College London, Department of Economics
}

Discussion Paper No. 156
May 2000

IZA

P.O. Box 7240

D-53072 Bonn

Germany

Tel.: +49-228-3894-0

Fax: +49-228-3894-210

Email: iza@iza.org

This Discussion Paper is issued within the framework of IZA's research area Mobility and Flexibility of Labor Markets. Any opinions expressed here are those of the author(s) and not those of the institute. Research disseminated by IZA may include views on policy, but the institute itself takes no institutional policy positions.

The Institute for the Study of Labor (IZA) in Bonn is a local and virtual international research center and a place of communication between science, politics and business. IZA is an independent, nonprofit limited liability company (Gesellschaft mit beschränkter Haftung) supported by the Deutsche Post AG. The center is associated with the University of Bonn and offers a stimulating research environment through its research networks, research support, and visitors and doctoral programs. IZA engages in (i) original and internationally competitive research in all fields of labor economics, (ii) development of policy concepts, and (iii) dissemination of research results and concepts to the interested public. The current research program deals with (1) mobility and flexibility of labor markets, (2) internationalization of labor markets and European integration, (3) the welfare state and labor markets, (4) labor markets in transition, (5) the future of work, (6) project evaluation and (7) general labor economics.

IZA Discussion Papers often represent preliminary work and are circulated to encourage discussion. Citation of such a paper should account for its provisional character. 
IZA Discussion Paper No. 156

May 2000

\section{ABSTRACT \\ Language Proficiency and Labour Market Performance of Immigrants in the UK*}

This paper uses two recent UK surveys to investigate labour market performance, the determinants of language proficiency, and the effect of language on earnings and employment probabilities of non-white immigrants. Our results show that language acquisition, employment probabilities, as well as earnings differ widely across non-white immigrants, according to their ethnic origin. Language has a strong and positive effects on employment probabilities. Furthermore, lack of English fluency leads to substantial earnings losses of immigrants. While earnings of white and ethnic minority natives develop in a similar manner, there is a large earnings gap between these two groups, and ethnic minority immigrants. English fluency contributes considerably to reducing these differences. Addressing the problems of measurement error and unobserved heterogeneity in language variables, our results indicate that measurement error in the language variable leads to underestimation of the importance of language for employment probabilities and earnings in straightforward regressions. In comparison with results found for other countries, language proficiency seems to be more important for labour market outcomes of UK immigrants.

JEL Classification: J15, J24, J61, R23

Keywords: Economics of minorities, human capital formation, immigrant workers

Christian Dustmann

University College London

Department of Economics

Gower Street

London WC1E 6BT

UK

Tel: +44 (0)1715045212

Fax: +44 (0)1715045212

Email: c.dustmann@ucl.ac.uk

\footnotetext{
*We are grateful to Barry Chiswick and lan Preston for comments on earlier drafts of this paper.
} 


\section{Introduction}

According to the 1994 Labour Force Survey, ethnic minorities account for almost 5.5 per cent of the overall population of B ritain, and for 6 per cent of its working-age population. Minorities are concentrated in the areas of Greater London and of the West Midlands, where they account for $20 \%$ and for more than $14 \%$ of the population respectively (see Sly (1995) and Green and Owen (1995) for more details).

Issues surrounding the economic performance and well being of minorities have received a lot of attention in public discussion in Britain. The question of economic assimilation has always played a major role in the immigration debate. There seems to be an understanding that economic assimilation is socially desirable, and policy makers should support this process, either by programmes aimed at the resident migrant population, or by selection of incoming immigrants.

A number of recent studies analyse various aspects of labour market behaviour of ethnic minorities, and compare outcomes with those of the majority population (see e.g. Blackaby et al. (1994, 1997)). In much of this literature, however, no attempt is made to distinguish between immigrant and British born minorities. But many important questions are speci ${ }^{-}$cally related to ${ }^{-}$rst generation immigrants, who constitute a signi ${ }^{-}$cant fraction of minorities in the UK. Out of a total of 2.6 million individuals belonging to ethnic minorities, over half are foreign born (Sly (1995)). This percentage is even higher when considering ethnic minorities of working age, where 73\% are born abroad (Sly (1995)). We show in this paper that native born and migrant minority populations di ßer quite 
substantially in terms of their economic success, and that distinguishing the two groups is important for addressing identi ${ }^{-}$cation of economic di ßerences.

Substantial initial earnings disadvantages of immigrants, as observed in a number of studies for the US (see, e.g. Chiswick (1978), Borjas (1985)), are often explained by migrants having lower levels of human capital when arriving in the host economy. The process of economic assimilation of immigrants depends then on the intensity with which they acquire host country speci ${ }^{-} \mathrm{c}$ skills. For the UK, the economic assimilation of immigrants has been analysed in papers by Chiswick (1980), B ell (1997), and Shields and Wheatley-Price (1998)). Chiswick (1980) uses data from the 1972 GHS. His main - nding is that, while white immigrants have very similar earnings pattern to native-born individuals, earnings of coloured immigrants are about 25 percent lower, other things the same. This gap is not decreasing with time of residence in the UK. In a more recent paper, Bell (1997) uses also data from the General Household Survey, but he pools waves between 1973 to 1992 . Like Chiswick, he ${ }^{-}$nds that white immigrants are doing surprisingly well. W hile white immigrants have an initial wage advantage, compared to native workers, black immigrants have an earnings disadvantage, but wage di ßerentials between this group and white natives decrease with the time spent in the UK. Shields and Wheatly-P rice (1998) use data from the British Labour Force Survey. They emphasise the di ßerent assimilation pattern between foreign and native born minority individuals.

It may be in the interest of the host country to support the process of economic assimilation. To achieve this, it is important to understand the factors which determine 
the economic performance of minority immigrants. In this paper, we concentrate on one speci ${ }^{-}$c human capital factor, which is important not only for immigrants' economic assimilation, but also for their social integration: Language. Recent analyses for the US, Canada, A ustralia, Israel, and Germany show that ${ }^{\circ}$ uency and literacy in the dominant host country language are important components for explaining immigrants' labour market success (see, e.g., Rivera-Batiz (1990), Chiswick (1991), Chiswick and Miller (1995), Chiswick, Cohen and Zach (1997), Dustmann (1994)). Work by Shields and WheatleyPrice (1999) indicates that language is also positively related to occupational success of some immigrant groups in the UK.

Enforcement and support of language acquisition is a possible policy instrument. If the returns to language capital are su \pm ciently large, governments may ${ }^{-}$nd it worthwhile to invest into programmes which enhance language skills of immigrants. Whether implementation of language programmes is worthwhile depends on the size of the language e Rect on labour market outcomes. If it is small, the cost of language education, or screening of immigrants according to their language ${ }^{\circ}$ uency upon immigration, may outweigh the bene ${ }^{-} \mathrm{ts}$. It is therefore most important to obtain a reliable estimate of this coe \pm cient.

Some governments ${ }^{-}$nd it worthwhile to require, or to enforce language pro $^{-}$ciency for their immigrant population. Some countries have implemented very rigorous language tests for immigrant applicants (e.g. New Zealand, which even requires the partner of the applicant to be pro $^{-}$cient), while others require immigrants to undergo an intensive language education upon entry to the host country (e.g. Israel; see Eckstein and Weiss 
(1999) for details). So far, most European countries have been reluctant to implement policies which impose entry conditions requiring an array of skills of immigrant applicants, or which demand the acquisition of skills upon entry.

In this paper, we analyse the determinants of ${ }^{\circ}$ uency and literacy in the host language for immigrants belonging to ethnic minority groups, and on how it relates to their labour market performance. We ${ }^{-}$rst investigate factors in ${ }^{\circ}$ uencing the acquisition of the host country's language by the immigrant, such as education, age, and years of residence in the host country. We distinguish between education received in the host- and in the home countries.

We then analyse the extent to which language ability in ${ }^{\circ}$ uences labour market outcomes of immigrants. We focus on its eRect on employment probabilities, and on the level of earnings. We compare earnings paths of minority immigrants with ethnic minority and white native born individuals. Our results show similarities between native born whites and ethnic minority individuals, but dramatic di ßerences between these two groups, and foreign born minorities. Language is a most important determinant in explaining earnings di ßerences among these groups.

As the discussion indicates, it is most important to obtain a precise estimate of the eßect of language on labour market outcomes. Unfortunately, estimates of language coe \pm cients in straightforward regressions are bedeviled by two problems. First, as pointed out by B orjas (1994), language may be correlated with unobserved ability components which also a eect the outcome variable. Second, as stressed by Dustmann and vanSoest 
(1998), language measures usually reported in survey data may su Rer substantially from measurement error. The bias induced by these two problems points in opposite directions. We attempt to address both problems in this paper, and propose estimators which may help to reduce, or eliminate the bias.

We base our analysis on data from two UK surveys on ethnic minorities: the Fourth National Survey on Ethnic M inorities (F NSE M), which has been collected between 1993 and 1994, and the Family and Working Lives Survey (FW LS), which has been collected between 1994 and 1995. B oth data sets consist of two subsamples. The FW LS contains a main sample of the entire UK population, and a "boost" sample of individuals belonging to ethnic minorities. The FNSEM contains a main sample of respondents belonging to ethnic minorities, and a reference sample of individuals belonging to the white majority population. Both surveys include questions on social and economic conditions of the interviewees, and measures on language pro ${ }^{-}$ciency. Information in the two data sets is complementary. For instance, while the FNSEM only reports spoken language pro ${ }^{-}$ciency, the FWLS contains also information about reading and writing skills. Also, the FNSEM distinguishes between education acquired in home- and host economy, which is not available for the FWLS. U sing two datasets allows us to conduct comparable analyses to check the robustness of the results obtained.

The structure of the paper is as follows. Section 2 develops the estimation equations. Section 3 brie $^{\circ}$ y describes the data sets, and gives some descriptive statistics. Section 4 investigates language determinants. Section 5 analyses how language pro ${ }^{-}$ciency a Rects 
the individual's probability of being employed, and earnings, and draws comparisons between ethnic minority immigrants, and native white and ethnic minority individuals. Section 6 summarises the results obtained, and compares ${ }^{-}$ndings for the UK with those for other countries.

\section{Language and Labour M arket Outcomes}

The literature on migrants' earnings assimilation distinguishes between human capital which is speci ${ }^{-} \mathrm{c}$ to the host country, human capital which is speci ${ }^{-} \mathrm{c}$ to the home country, and human capital which is equally productive in both countries. Typically, immigrants enter the host country with skills which are only of limited use in the host economy, which results in an initial earnings disadvantage (see Chiswick (1978)). After immigration, migrants transfer home country speci ${ }^{-} \mathrm{c}$ human capital into general or host country speci $^{-} \mathrm{c}$ human capital, and acquire additional skills which are speci ${ }^{-} \mathrm{c}$ to the host country economy. The intensity of this process determines the speed of economic assimilation.

Language capital is a most important component of host country human capital. Furthermore, it is very speci ${ }^{-}$c to the host economy, since it is usually not transferable to the migrant's home economy. Standard human capital models may serve as a basis to formulate empirical speci ${ }^{-}$cations explaining the determinants of language capital. In such models, human capital is produced by investing time and other inputs. The cost of production equals forgone earnings, plus the cost of other input goods. A simple equilibrium condition states that investment into human capital production is set such 
that the cost equals the bene ${ }^{-} t$ from the discounted future enhanced earnings potential. The production potential may di ßer across individuals according to their ability to acquire knowledge, and it may depend on the stock of human capital acquired in the past. The bene ${ }^{-} \mathrm{t}$ of any acquisition of host country speci ${ }^{-}$c human capital depends, in addition, on the length of the period over which it is productively put into use. In the case of language capital of immigrants, this corresponds to the migration period.

Accordingly, investment into language capital should depend on its potential future bene $^{-} \mathrm{ts}$, on the cost of acquisition, and on the individual's e \pm ciency in producing it. Furthermore, it should be a ßected by the envisaged migration period. Variables which measure the immigrant's e \pm ciency in acquiring language capital are the level of education upon immigration, and the age at immigration (since the learning potential may deteriorate over the life cycle). The cost of acquiring the host country language depends on the distance of the migrant's mother tongue to the dominant majority language, which may be captured by country of origin dummies. Clearly, this last variable picks up a

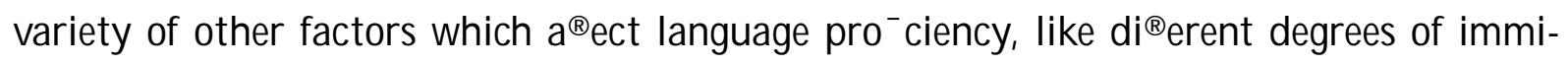
grant selection across countries (see Borjas $(1985,1987)$ ). A ssuming that all migrations are permanent, the time period over which any language capital is productive depends on the migrant's age at entry. A ccordingly, those who migrate at younger age should have a higher incentive to acquire language capital. The acquisition of language capital may, in addition, depend on the extent to which individuals are exposed to the language of the majority population. A variable which measures exposure is the time of residence abroad. 
Finally, it is likely that the value of language capital di ßers across locations in the host country, according to the relative size of the ethnic minority population the immigrant belongs to. Lazear (1999) develops a model where in each period individuals encounter each other and get involved into trade activities. Trade can only take place between individuals who have the same means of communication (language, for instance). The smaller the size of the minority population, the smaller is the probability that an individual of that population who is not ${ }^{\circ}$ uent in the native language will get involved into successful trading without mastering the host language. Accordingly, given the cost of language acquisition, the smaller the relative size of the minority population, the larger will be the probability that an individual acquires the native language. The empirical implication of this is that immigrants in areas of high ethnic concentration should be less pro ${ }^{-}$cient in the host language.

We summarise the factors which explain language acquisition in the vector of observed variables $z_{i}$, where $i$ is an index for the ith individual. The language equation can be written as

$$
\mathrm{I}_{i}=z_{i}^{0} \pm+u_{i} ;
$$

where $u_{i}$ is an error term. A ssumptions about $u_{i}$ determine the nature of the model and the properties of its estimator. 


\subsection{M easurement Error and U nobserved Heterogeneity}

A second objective of the paper is to analyse the eßect of language on labour market outcomes, in particular on wages and employment probabilities. Dustmann and van Soest (1998) discuss in detail the problems which may occur in straightforward regression analysis, where language is a regressor. First, the same unobserved heterogeneity components may a Rect both language (as discussed above), and economic performance, leading to an upward bias of estimated language eßects on economic outcomes. Second, unsystematic measurement error may lead to a downward bias of the eßect of language on earnings. Numbers presented in Dustmann and van Soest (1998) on repeated language information for the same individual suggest that measurement error is substantial in self-reported language measures. In fact, in their data, more than half of the within individual variation in language responses is due to measurement error. Their results suggest that the downward bias induced by measurement error overcompensates the upward bias induced by unobserved heterogeneity.

To explain the issues involved in more detail, consider a generic outcome function, where $y_{i}$ is log earnings or (the underlying index of) the employment equation respectively:

$$
y_{i}=x_{i}^{0-}+{ }^{\circ} I_{i}+\mathbb{Q}+v_{i} ;
$$

where $x_{i}$ are (exogenous) variables which determine the outcome variable, $l_{i}$ is the 'true' language pro' ciency of the individual, and $\mathrm{i}$ is an index for individuals, respectively.

The error term \& is unobserved individual heterogeneity, while $v_{i}$ is an idiosyncratic error 
term.

In the general model, we do not observe $I_{i}$, but only $r_{i}$. We assume that $r_{i}=I_{i}+{ }^{\prime} i$, where ${ }^{i}$ denotes an unsystematic measurement error.

Substitution in (2) gives

$$
y_{i}=x_{i}^{0-}+{ }^{\circ} r_{i}+\mathbb{Q}_{i}+v_{i}{ }^{\circ}{ }_{i}^{\prime}:
$$

Throughout, we assume that $\AA_{,},{ }_{i}$, and $v_{i}$ are independent of each other and of the $x_{i}$, and that the measurement error ${ }^{\prime} i$ is uncorrelated with $I_{i}$.

OLS on equation (3) leads to inconsistent estimates of ${ }^{\circ}$ if $E\left(\otimes_{Q}+v_{i} i^{\circ}{ }^{\prime} i j F_{i}\right) G 0$. This will generally be the case if there is measurement error, or if $I_{i}$ and the individual speci ${ }^{-}$c heterogeneity ${ }_{\circledR}$ are correlated.

The asymptotic bias of the OLS estimator is given by

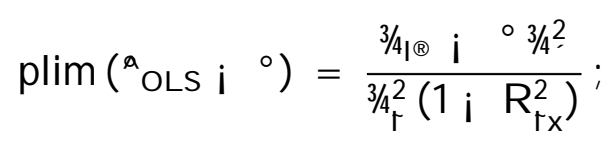

where $3 /{ }_{\circledast}$ is the covariance between $\AA$ and $I_{i}$, and $3 / 4$ the variance of the measurement error. Furthermore, $3 / 2$ is the variance of $r_{i}$, and $R_{r x}$ is the multiple correlation coe \pm cient in a regression of ron $\mathrm{x}$. The ${ }^{-}$rst term in the numerator is the bias due to unobserved heterogeneity. It is positive if the same unobserved component a ßects earnings and language pro- ciency in the same direction. The second term is the asymptotic (downward) bias due to measurement error. 
To give a structural interpretation to the language coe \pm cient, we need to deal with both sources of bias. We address the two issues separately. To deal with the measurement error, we use IV estimation. A s instruments, we use information on the language in which the survey interview has been conducted, information which is available in one of our datasets (the F NSEM). These instruments are however still correlated with unobserved heterogeneity components. To reduce the bias due to unobserved heterogeneity, we add partner variables and household characteristics to the earnings equation. These variables are likely to be correlated with the unobserved heterogeneity component in language and outcome equation. Inclusion of these background characteristics may therefore reduce the correlation between $\circledast$ and $\mathrm{I}_{\mathrm{it}}$, thus reducing the bias. The resulting OLS estimator can be interpreted as a matching estimator in the sense of Rosenbaum and Rubin (1983). If, conditional on these background characteristics, $I_{i}$ is uncorrelated with $\circledast$, this procedure eliminates the bias due to unobserved heterogeneity.

\section{The Data}

The Family and Working Lives Survey (FW LS) has been collected in 1994 and 1995. It is a retrospective survey on adults aged between 16 and 69, including 9000 respondents and their partners. It contains a "boost" sample of about 2000 individuals belonging to four racial minority groups: Black Caribbeans, Indians, Pakistanis and B angladeshis. The data provides information on earnings, education, nationality, language skills and parents' economic and educational status. Of the 2388 people forming the minority sample in the 
main and "boost" sample, 68\% (1639) are foreign born.

The Fourth National Survey on Ethnic M inorities (F NSE M) is also a cross- sectional survey, which has been carried out between 1993 and 1994. Individuals included are aged 16 or more, and of Caribbean, Indian, Pakistani, Bangladeshi, or Chinese origin. There are 5196 observations in the minority sample, and 2867 observations in the independent comparison sample of white individuals. Similarly to the FW LS, more than 77\% (4019) of the individuals in the ethnic minority sample are foreign born.

The FWLS identi ${ }^{-}$es the ward where the individual lives. It is therefore possible to match this data set with the 1991 Population Census to construct a variable on the ethnic concentration on ward level. The F NSE M does not contain geographical identi ${ }^{-}$ers; therefore, matching with the Census data is not possible. It contains however grouped information on ethnic concentration at ward level.

B oth data sets provide information on earnings. The FWLS reports gross (before tax) earnings, while the F NSEM reports grouped gross weekly earnings. Both data sets report the main activity of the individual (e.g. full-time or part-time paid work, full-time education, unemployed, etc.).

The sample design of the two surveys di ßers substantially. The ethnic minority sample of the FWLS was selected by screening addresses in areas where the ethnic minority population, according to the 1991 census, was more than 3\% of the local population. The selection in the FNSEM was more complex, considering wards with any percentage of ethnic minorities on the population and oversampling Bangladeshis to obtain a su \pm cient 
sample size. For more details, see Appendix 1 in Modood et al. (1997), and Smith and Prior (1996).

Table 1 shows the percentage of immigrants belonging to ethnic minorities with respect to the overall population in the UK (column 1), and the ethnic composition within the group of ethnic immigrants. Numbers are based on the 1991 Census. Table 2 gives the ethnic composition of the two surveys. B oth surveys do not include Black A frican immigrants, and the FWLS does not include the Chinese minority. In the last column of table 1, we report respective numbers in the census, excluding A fricans. Comparing the two tables, it appears that both surveys tend to oversample the South A sian groups (Indians, Pakistanis and Bangladeshis). A Iso, the two surveys di ßer in the ethnic composition of the respondents: Bangladeshis amount to $31 \%$ in the FW LS and $14 \%$ in the F NSE M, Indians to $19 \%$ in the FWLS and $24 \%$ in the F NSE M and A frican A sians to $8 \%$ in the FWLS and $17 \%$ in the F NSEM.

Table 1: Ethnic Immigrants Composition in the UK (Census 1991)

\begin{tabular}{l|ccc}
\hline \hline & $\begin{array}{c}\text { Immigrants Perc. } \\
\text { wrt UK Pop. }\end{array}$ & Ethnic composition & $\begin{array}{c}\text { Ethnic composition } \\
\text { without Africans }\end{array}$ \\
\hline Caribbean & 0.56 & 18.19 & 23.41 \\
Indian & 0.84 & 27.57 & 35.49 \\
African & 0.68 & 22.31 & - \\
Bangladeshi & 0.22 & 7.09 & 9.13 \\
Pakistani & 0.47 & 15.46 & 18.89 \\
South East A sians & 0.29 & 9.37 & 12.06 \\
\hline Total & 3.06 & 100 & 100 \\
\hline
\end{tabular}


Table 2: Ethnic Composition

\begin{tabular}{l|rrrrr}
\hline \hline Variable & \multicolumn{2}{|c}{ FWLS } & \multicolumn{3}{c}{ F NSEM } \\
\hline & No. & Perc. & No. & Perc. & Perc. \\
\hline Black Caribbeans & 265 & 16.17 & 698 & 18.20 & 17.37 \\
Indians & 314 & 19.16 & 971 & 25.32 & 24.17 \\
Afro-A sian & 123 & 7.50 & 656 & 17.11 & 16.32 \\
Pakistanis & 425 & 25.93 & 960 & 25.05 & 23.89 \\
Bangladeshis & 512 & 31.24 & 550 & 14.34 & 13.68 \\
Chinese & - & - & 184 & - & 4.58 \\
\hline Total & 1639 & 100 & 4019 & 100 & 100 \\
\hline \multicolumn{1}{l}{} & \multicolumn{7}{c}{} \\
\hline \hline
\end{tabular}

B oth surveys contain information on language. In the FWLS, language ability is selfassessed. The individual is ' ${ }^{-}$st asked whether s/ he speaks English as mother tongue. If not, the individual is asked to self-assess pro ${ }^{-}$ciency in speaking, reading, and writing English on a 5 point scale. The F NSEM contains two variables which are related to language pro $^{-}$ciency: ${ }^{-}$rst, the interviewer's evaluation on the individual's spoken language ability, on a 4 point scale. Second, information about what fraction of the interview was held in English.

In Table A 1 we display the complete responses to the language questions for the two data sets, broken down according to ethnic origin. The general pattern is similar for the two data sets. In fact, the percentage of individuals ${ }^{\circ}$ uent or very ${ }^{\circ}$ uent in English in the FNSEM equals the percentage of individuals speaking English as ${ }^{-}$rst language plus the percentage of individuals ${ }^{\circ}$ uent or very ${ }^{\circ}$ uent in the FWLS.

For the empirical analysis, we re-de ne the language indicators in the two surveys to dichotomous variables. For the FW LS, this variable assumes the value 1 if the individual reports language ${ }^{\circ}$ uency or literacy as "well" or "very well", or reports English as a " rst 
Language. For the FNSEM, it is equal to 1 if individuals fall in the categories "fairly well" or " "uently".

Table 3 explains the variables used for the analysis, and presents summary statistics. The mean values on language indicate that the percentage of individuals who speaks the English language well or very well is very similar in the two samples. Percentages for reading and writing in English (available in the FW LS) are slightly lower.

Table 3: Variables Description and Sample Characteristics

\begin{tabular}{|c|c|c|c|c|c|}
\hline Variable & \multicolumn{2}{|c|}{ FWLS } & \multicolumn{2}{|c|}{ FNSEM } & Description \\
\hline & M ean & S.D. & M ean & S.D. & \\
\hline Speak & 0.709 & 0.454 & 0.691 & 0.462 & Dummy $=1$ if spoken English is good or very good \\
\hline Read & 0.671 & 0.469 & - & - & Dummy $=1$ if read English is good or very good \\
\hline Write & 0.641 & 0.479 & - & - & Dummy $=1$ if written English is good or very good \\
\hline E mpl & 0.367 & 0.482 & 0.425 & 0.494 & Dummy $=1$ if employed \\
\hline Unempl & 0.162 & 0.369 & 0.138 & 0.345 & Dummy $=1$ if unemployed \\
\hline W gearn & 239.175 & 432.809 & 221.185 & - & Weekly gross earnings \\
\hline Sex & 0.468 & 0.499 & 0.505 & 0.500 & Dummy $=1$ if male \\
\hline Age & 38.347 & 13.588 & 42.604 & 14.407 & Age \\
\hline Yearstay & 20.404 & 10.313 & 21.367 & 10.001 & Years of stay in the UK \\
\hline M arried & 0.726 & 0.446 & 0.776 & 0.417 & Dummy=1 if married \\
\hline Nchild & 1.937 & 1.793 & 1.654 & 1.761 & Number of children in household \\
\hline Degree & 0.072 & 0.258 & 0.127 & 0.333 & Dummy=1 if university degree \\
\hline Alev & 0.129 & 0.335 & 0.109 & 0.312 & Dummy $=1$ if high vocational \\
\hline Voc & 0.231 & 0.422 & 0.230 & 0.421 & Dummy $=1$ if low vocational \\
\hline Noqual & 0.568 & 0.495 & 0.533 & 0.499 & Dummy $=1$ if no quali ${ }^{-}$cation \\
\hline Immcon & 0.090 & 0.094 & - & - & Ward own ethnic immigrants concentration \\
\hline Ethcon & 0.168 & 0.153 & 0.166 & 0.189 & Ward own ethnic concentration \\
\hline Carib & 0.1620 & 0.369 & 0.178 & 0.383 & Dummy $=1$ if Black Caribbean \\
\hline Indian & 0.1860 & 0.389 & 0.245 & 0.429 & Dummy $=1$ if Indian \\
\hline A froas & 0.0838 & 0.277 & 0.169 & 0.375 & Dummy $=1$ if A frican A sian \\
\hline Pakista & 0.255 & 0.436 & 0.218 & 0.413 & Dummy= 1 if Pakistani \\
\hline Chinese & & & 0.048 & 0.214 & Dummy $=1$ if Chinese \\
\hline Bangla & 0.318 & 0.466 & 0.142 & 0.349 & Dummy $=1$ if $B$ angladeshi \\
\hline
\end{tabular}

A bout $40 \%$ of the sample populations are employed, and $33 \%$ out of the labour force. 
These numbers are remarkably similar for the two data sets. Furthermore, 16\% (FWLS) and $14 \%$ (F NSE M) report being unemployed.

The mean value of weekly wages in the FWLS is $\$ 239.17$, considering both part and full-time workers. M ean weekly wage are reported in the F NSEM as a grouped variable. The mean weekly gross wage is $221 \$$, which is similar to the mean wage in the FW LS. ${ }^{1}$

The average education level is slightly higher in the F NSEM than in the FWLS, with $12.7 \%$ graduates in the former sample, and only $7.2 \%$ in the latter sample. Furthermore, there is a slightly higher percentage of individuals with no quali ${ }^{-}$cation in the FWLS $(56.8 \%)$ than in the F NSEM $(53.3 \%) .^{2}$

The average ethnic minority concentration at ward level amounts, in both samples, to more than $16 \%$ (the average ward concentration in the F NSE M is obtained by taking the average of the mid-point values of the grouped variable, since the information is available only in intervals). The considerable di Rerence in the sample designs is $\mathrm{re}^{\circ}$ ected only by the larger standard deviation indicated in the F NSE M.

In Table A2, we break down means of the age at immigration, year of immigration, and age for the various ethnic groups. In the FW LS, individuals are on average four years younger than in the F NSEM, and have immigrated at a younger age. The immigration patterns for the various ethnic groups are similar in both data sets, and correspond to the migration patterns indicated by Bell (1997) and Hutton and Wheatley Price (1999):

\footnotetext{
${ }^{1}$ To obtain this number, we estimate a grouped regression model (see Steward, 1983) on a constant, and compute the mean of the predictions.

${ }^{2}$ We construct the education variables following a classi ${ }^{-}$cation by Dearden (1999).
} 
Black Caribbeans arrivals are concentrated in the late 1950's and early 1960 's, whereas Indians, A frican A sians and Pakistanis arrived mainly during the 1970 's, and B angladeshis towards the end of the 1970 's. Consistent with their shorter stay, Bangladeshis are the youngest group, whereas Black Caribbeans are the oldest on average.

\section{Language Determinants}

After eliminating all the observations with missing values in the variables of interest, we are left with 1475 observations in the F W LS sample, and 3732 observations in the F NSE M sample.

Table 4 reports results from straightforward probit regressions, where the indicator variable equals one if the individual is pro ${ }^{-}$cient in the respective language component. We report marginal eßects, evaluated at average sample characteristics. Comparing results on spoken language for the two data sets shows that the signs of regressors are equal for both samples in most cases, and the sizes of the coe \pm cients are likewise similar (although the coding of the ${ }^{\circ}$ uency variables di ßers slightly). Females have a signi ${ }^{-}$cantly lower probability to be ${ }^{\circ}$ uent in the majority language. The e®ect of age (which corresponds to the eßect of age at entry, since we condition on years of residence) is negative and strongly signi $^{-}$cant, and the years of residence variable has the expected positive eßect. All these results are consistent with ${ }^{-}$ndings for other countries. Furthermore, for the FWLS, the eßect of these variables is similar for all three components of language capital.

The eßect of the education variables is quite strong for ${ }^{\circ}$ uency (the comparison group 
are individuals who report to have no quali ${ }^{-}$cation): For the FW LS (FNSEM) individuals with vocational training have a 23 (17) percent higher probability of being ${ }^{\circ}$ uent in English. The association between ${ }^{\circ}$ uency and higher educational degrees is not stronger, though.

Speaking ${ }^{\circ}$ uency may largely be acquired by exposure to the host country language, while writing and reading in a foreign language is a skill which is more di \pm cult to obtain. Acquisition requires a more systematic way of learning, and the general level of schooling obtained may enhance the e \pm ciency of acquiring this component of language capital. This is re ected by our results, which indicate that educational background variables have larger coe \pm cients for reading and writing skills. ${ }^{3}$

\footnotetext{
${ }^{3}$ T he variable "degree" predicts outcomes perfectly. Individuals with degrees do therefore not contribute to the likelihood, since $\mathrm{Prob}(\mathrm{F}$ luent $)=1($ Degree $=1)+1($ Degree $=0) \operatorname{Prob}\left(z_{i}^{0} \pm>i u_{i}\right) .1(:)$ is an indicator function, which does not depend on the parameter vector \pm Estimations are therefore performed on the sample of non-degree holders.
} 
Table 4: Language determinants, Probit Estimation

\begin{tabular}{|c|c|c|c|c|c|c|c|c|c|c|}
\hline & \multicolumn{6}{|c|}{ FW LS } & \multicolumn{4}{|c|}{ F NSEM } \\
\hline \multirow[t]{3}{*}{ Variable } & \multirow{2}{*}{\multicolumn{2}{|c|}{ Speaking }} & \multicolumn{2}{|c|}{ Reading } & \multicolumn{2}{|c|}{ Writing } & \multicolumn{4}{|c|}{ Speaking } \\
\hline & & & & & \multicolumn{3}{|c|}{ All Quali' cations } & \multicolumn{2}{|c|}{ UK/nonUK Q } & \\
\hline & $\mathrm{ME}$ & t-ratio & $\mathrm{ME}$ & t-ratio & $\mathrm{ME}$ & t-ratio & $\mathrm{ME}$ & t-ratio & ME & t-ratio \\
\hline sex & 0.109 & 4.95 & 0.138 & 5.06 & 0.103 & 3.85 & 0.148 & 10.19 & 0.139 & 9.85 \\
\hline age & -0.006 & -6.10 & -0.008 & -6.38 & -0.007 & -5.34 & -0.012 & -18.30 & -0.010 & -15.85 \\
\hline yearstay & 0.008 & 5.40 & 0.009 & 4.76 & 0.007 & 3.71 & 0.013 & 14.07 & 0.011 & 11.81 \\
\hline degree & 0.185 & 5.93 & \{ & \{ & 0.286 & 7.64 & 0.221 & 16.12 & \{ & \{ \\
\hline Alevtea & 0.208 & 8.24 & 0.301 & 9.35 & 0.309 & 10.41 & 0.178 & 11.38 & \{ & \{ \\
\hline OlevCSE & 0.226 & 10.98 & 0.308 & 11.85 & 0.316 & 13.12 & 0.172 & 12.78 & \{ & \{ \\
\hline E degree & \{ & \{ & \{ & \{ & \{ & \{ & \{ & \{ & \{ & \{ \\
\hline EA levtea & \{ & \{ & \{ & \{ & \{ & \{ & \{ & \{ & 0.188 & 6.34 \\
\hline EOlevCSE & \{ & \{ & \{ & \{ & \{ & \{ & \{ & \{ & 0.209 & 9.56 \\
\hline F degree & \{ & \{ & \{ & \{ & \{ & \{ & \{ & \{ & 0.177 & 13.40 \\
\hline FAlevtea & \{ & \{ & \{ & \{ & \{ & \{ & \{ & \{ & 0.117 & 5.74 \\
\hline FOlevCSE & \{ & \{ & \{ & \{ & \{ & \{ & \{ & \{ & 0.114 & 8.00 \\
\hline married & -0.067 & -2.61 & -0.090 & -2.75 & -0.073 & -2.27 & -0.039 & -2.07 & -0.012 & -0.66 \\
\hline nchild & -0.010 & -1.67 & -0.009 & -1.29 & -0.020 & -2.65 & -0.005 & -1.34 & -0.005 & -1.25 \\
\hline indian & 0.164 & 6.75 & 0.202 & 6.31 & 0.192 & 5.92 & 0.064 & 3.16 & 0.072 & 3.75 \\
\hline afroas & 0.181 & 5.75 & 0.235 & 5.57 & 0.203 & 4.84 & 0.176 & 10.09 & 0.165 & 9.93 \\
\hline pakista & 0.093 & 4.10 & 0.061 & 1.99 & 0.065 & 2.14 & -0.025 & -1.23 & -0.009 & -0.45 \\
\hline carib & 0.244 & 8.55 & 0.346 & 9.45 & 0.352 & 10.11 & 0.309 & 13.77 & 0.297 & 13.89 \\
\hline chinese & \{ & \{ & \{ & \{ & \{ & \{ & 0.042 & 1.33 & 0.007 & 0.22 \\
\hline ethcon & -0.467 & -4.68 & -0.402 & -3.23 & -0.201 & -1.63 & -0.198 & -5.75 & -0.209 & -6.15 \\
\hline No. of Obs. & \multicolumn{2}{|c|}{1589} & \multicolumn{2}{|c|}{1475} & \multicolumn{2}{|c|}{1589} & \multicolumn{2}{|c|}{3732} & \multicolumn{2}{|c|}{3552} \\
\hline Obs. Prob. & \multicolumn{2}{|c|}{0.710} & \multicolumn{2}{|c|}{0.646} & \multicolumn{2}{|c|}{0.641} & \multicolumn{2}{|c|}{0.691} & \multicolumn{2}{|c|}{0.675} \\
\hline Pred. Prob. & \multicolumn{2}{|c|}{0.835} & \multicolumn{2}{|c|}{0.757} & \multicolumn{2}{|c|}{0.757} & \multicolumn{2}{|c|}{0.841} & \multicolumn{2}{|c|}{0.852} \\
\hline \multicolumn{11}{|c|}{$\begin{array}{l}\text { ME : M arginal E Rects, evaluated at sample means. } \\
\text { Excluded categories: no education quali }{ }^{-} \text {cation, B angladeshi. } \\
\text { Ethnic concentration for F NSEM at mid-point }\end{array}$} \\
\hline
\end{tabular}

Education may be partly obtained in the host country. Since those who wish to enter the educational system in the UK are likely to have acquired some language skills, this leads to a classical simultaneity bias.

The F NSEM allows distinguishing between education obtained in the UK and abroad. We have re-estimated the language equation, distinguishing between education obtained overseas, and in the UK. R esults are reported in the last column of table 4 . We denote by $F$ 
educational achievements obtained abroad, and by $\mathrm{E}$ educational achievements obtained in the UK ${ }^{4}$ The eRect of overseas quali ${ }^{-}$cations on language ${ }^{\circ}$ uency is still positive, but slightly lower than the eßect of education obtained in the UK. These di ßerences in the coe \pm cients are statistically signi ${ }^{-}$cant at the 1 percent level.

The variable NCHILD measures the number of children in the household. Chiswick and M iller (1995) suggest that children may have counteracting eßects on language: " rst, they may act as a translator between the parent and the English environment (thus reducing incentives to learn the foreign language). Second, they may enhance exposure to the majority population by forcing the parent to cope with institutional matters, like school and parents of native friends of children. Our results indicate that children coe \pm cients are negative for both data sets, and for all language components.

There are large di ßerences in the level of language pro ${ }^{-}$ciency among di ßerent ethnic groups. Results of both data sets indicate that Bangladeshis, the excluded group, are dominated by nearly all other ethnic groups, except for Pakistanis in the F NSEM.

The variable ethcon measures ethnic concentration of the own minority at ward level. It is strongly associated with language pro ${ }^{-}$ciency for both data sets. Results from the FW LS indicate that an increase in the ethnic density by 1 percentage point is associated with a 0.47 percent decrease in the probability to be ${ }^{\circ}$ uent in the dominant language. The negative association with reading and writing skills is slightly smaller. Results from the F NSEM also indicate a negative association, but the size of the coe \pm cient is only half

\footnotetext{
${ }^{4}$ Since "E degree" predicts outcomes perfectly, estimation is performed on those who do not hold a UK degree. See footnote 2 .
} 
as large as that for the FWLS. Similar results are found for the US, Canada and Israel (see Chiswick (1994), and Chiswick and Miller (1995)).

Clearly, if individuals are free to choose their location, the ethnic density coe \pm cient measures a compound e®ect, consisting of the direct e®ect (which corresponds to the e®ect of ethnic concentration on language when assigning individuals randomly to areas with di ßerent concentrations), and an indirect eßect (which results from individuals sorting to neighbourhoods with di ßerent concentration, according to their potential to learn the language). As Lazear (1999) points out, both are consistent with his model of language being a means of decreasing the cost of trading.

However, for many policy related questions (e.g. settlement policies of arriving immigrants) it may be interesting to disentangle these two e®ects. To identify the causal e Rect of ethnic concentration is di \pm cult, since it requires instruments which a $\mathbb{R e c t}$ location choice, but not language acquisition. In a companion paper (Dustmann, Fabbri and Preston (2000)), we develop a model which shows that the bias due to sorting may go in both directions, and we suggest identi ${ }^{-}$cation strategies.

\section{Language and Economic Outcomes}

\subsection{Employment Probabilities}

Language pro ${ }^{-}$ciency is likely to be a decisive factor in determining employment probabilities. Language may help to acquire information about optimal job search strategies. 
M igrants who are not su \pm ciently pro $^{-}$cient in the dominant language may have di \pm culties to convince prospective employers of their quali ${ }^{-}$cations. Also, many jobs, for instance in the service sector, require communicative skills; likewise, literacy in the dominant language is a crucial prerequisite for many unskilled occupations.

To understand the association between employment probabilities and language, we consider individuals who are in the labour force, and we distinguish between those who are in work, and those who are not employed, but who are actively seeking a job. ${ }^{5}$ Our samples consist of 849 individuals for the FWLS, and 2165 individuals for the FNSEM. Our dependent variable, EMPL, takes the value 0 if the individual is unemployed and seeking a job or claiming bene ${ }^{-}$ts, and the value 1 if the individual works full- or part-time. Explanatory variables are the demographic and human capital characteristics available in the two data sets, including a dummy variable for the level of language pro $^{-}$ciency.

The results are reported in Table 5. We estimate probit models, and report marginal e eects, evaluated at the mean vector of sample characteristics. For the FW LS, we report results conditioning on ${ }^{\circ}$ uency only, and on ${ }^{\circ}$ uency and written literacy.

Most coe \pm cient estimates for the two data sets are very similar. Females have a sig$\mathrm{ni}^{-}$cantly higher probability of being employed (14 percent in the FWLS, and 10 percent in the FNSE M). B eing married increases employment probabilities by about 20 (23) percentage points. Having children in ${ }^{\circ}$ uences, on the other side, the employment probability

\footnotetext{
${ }^{5} \mathrm{~T}$ his follows the ILO de- nition of unemployment. According to the ILO de nition, people are considered as unemployed if aged 15 years or older, who are without work, but available to start within the next two weeks, and who have actively sought employment at some time during the previous four weeks.
} 
negatively. These e®ects are consistent with evidence for B ritish natives. Nickell (1980) - nds that married individuals are about 30\% more likely to being employed than unmarried ones. His interpretation for this - ndings is that married individuals may have more responsibilities towards their families, and have a more stable working record, both increasing their employment probabilities.

For the FWLS, education coe \pm cients are mostly insigni- cant. For the FNSEM, education coe \pm cients are signi ${ }^{-}$cant, and in the expected order of magnitude. In the last columns of table 5, we run regressions which distinguish between education levels acquired in the UK, and in the home country. The coe \pm cients on the UK educational degrees seem larger than the coe \pm cients on education acquired at home. However, only for A-levels can we reject the null hypothesis that the coe \pm cients are equal (and only at the 10 percent level). 
Table 5: Employment probabilities

\begin{tabular}{|c|c|c|c|c|c|c|c|c|c|c|}
\hline & \multicolumn{6}{|c|}{ FW LS } & \multicolumn{4}{|c|}{ F NSEM } \\
\hline \multirow[t]{3}{*}{ Variable } & \multicolumn{2}{|c|}{1} & \multicolumn{2}{|c|}{2} & \multicolumn{2}{|c|}{3} & \multicolumn{4}{|c|}{4} \\
\hline & & & & & & & \multicolumn{2}{|c|}{ All Quali' cations } & \multicolumn{2}{|c|}{ UK/nonUK Q } \\
\hline & Coe $\AA$ & t-ratio & Coe $\AA$ & t-ratio & $\mathrm{Coe} \circledast$ & t-ratio & $\mathrm{Coe} \circledast$ & t-ratio & Coe $\AA$ & t-ratio \\
\hline sex & -0.143 & -3.81 & -0.138 & -3.69 & -0.140 & -3.74 & -0.102 & -4.69 & -0.100 & -4.62 \\
\hline married & 0.207 & 4.32 & 0.208 & 4.33 & 0.210 & 4.36 & 0.229 & 7.40 & 0.231 & 7.48 \\
\hline nchild & -0.035 & -2.93 & -0.034 & -2.82 & -0.034 & -2.83 & -0.025 & -4.05 & -0.025 & -4.05 \\
\hline degree & 0.072 & 1.19 & 0.043 & 0.68 & 0.043 & 0.67 & 0.112 & 4.08 & \{ & \{ \\
\hline Alevtea & 0.004 & 0.09 & -0.020 & -0.40 & -0.022 & -0.43 & 0.124 & 4.41 & \{ & \{ \\
\hline OlevCSE & -0.071 & -1.65 & -0.093 & -2.07 & -0.095 & -2.10 & 0.073 & 3.31 & \{ & \{ \\
\hline E degree & \{ & \{ & \{ & \{ & \{ & \{ & \{ & \{ & 0.112 & 3.00 \\
\hline EA levtea & \{ & \{ & \{ & \{ & \{ & \{ & \{ & \{ & 0.139 & 4.20 \\
\hline EOlevCSE & \{ & \{ & \{ & \{ & \{ & \{ & \{ & \{ & 0.068 & 2.61 \\
\hline F degree & \{ & \{ & \{ & \{ & \{ & \{ & \{ & \{ & 0.090 & 2.69 \\
\hline FAlevtea & \{ & \{ & \{ & \{ & \{ & \{ & \{ & \{ & 0.065 & 1.57 \\
\hline FOlevCSE & \{ & \{ & \{ & \{ & \{ & \{ & \{ & \{ & 0.063 & 2.37 \\
\hline age & 0.028 & 2.81 & 0.029 & 2.94 & 0.029 & 2.95 & 0.013 & 2.34 & 0.013 & 2.24 \\
\hline agesq/ 100 & -0.038 & -3.15 & -0.040 & -3.30 & -0.040 & -3.29 & -0.021 & -3.08 & -0.020 & -2.98 \\
\hline yearstay & 0.003 & 1.31 & 0.003 & 1.43 & 0.003 & 1.32 & 0.003 & 2.33 & 0.002 & 1.88 \\
\hline black & 0.095 & 1.61 & 0.083 & 1.39 & 0.080 & 1.32 & 0.078 & 2.18 & 0.077 & 2.14 \\
\hline afroas & 0.117 & 2.05 & 0.120 & 2.13 & 0.115 & 2.00 & 0.146 & 4.68 & 0.144 & 4.59 \\
\hline indian & 0.165 & 3.41 & 0.166 & 3.46 & 0.161 & 3.31 & 0.118 & 3.85 & 0.119 & 3.90 \\
\hline pakista & 0.055 & 1.22 & 0.061 & 1.38 & 0.057 & 1.27 & 0.006 & 0.21 & 0.009 & 0.32 \\
\hline chinese & \{ & \{ & \{ & \{ & \{ & \{ & 0.179 & 4.73 & 0.175 & 4.55 \\
\hline speak & 0.152 & 3.01 & \{ & \{ & 0.048 & 0.73 & 0.172 & 5.99 & 0.168 & 5.86 \\
\hline write & \{ & \{ & 0.173 & 3.63 & 0.140 & 2.19 & \{ & \{ & \{ & \{ \\
\hline \multirow[t]{2}{*}{ N. of Obs. } & \multicolumn{2}{|c|}{839} & \multicolumn{2}{|c|}{839} & \multicolumn{2}{|c|}{839} & \multicolumn{2}{|c|}{2100} & \multicolumn{2}{|c|}{2100} \\
\hline & Exclude & 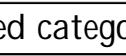 & $\therefore n$ & & & & deshi. & & & \\
\hline
\end{tabular}

Age is positively associated with employment probabilities, and the age pro ${ }^{-}$le is concave. The time of residence in the UK has a positive e®ect on employment probabilities, but it is small, and not signi ${ }^{-}$cant for the FWLS. Indians, A fro-A sians and Chinese have higher probabilities of being employed than Pakistanis and Bangladeshis. Again, Bangladeshis seem to be the most disadvantaged group.

The coe \pm cients on the language variables are quite large. English ${ }^{\circ}$ uency is associated 
with a 15 percent (17 percent) higher employment probability, using the F W LS (F NSE M ) data. The coe \pm cients are highly signi ${ }^{-}$cant, and coe \pm cients are remarkably similar for the two data sets.

The FW LS data distinguishes between speaking, writing and reading abilities $\{$ information which is not available in most datasets on migrants' language abilities. O ne may argue that pro $^{-}$ciency in the spoken language alone is not su \pm cient to a Rect labour market outcomes, but that writing skills are likewise needed. The positive coe \pm cient of the ${ }^{\circ}$ uency variable may then simply re ${ }^{\circ}$ ect the correlation between these two components of language capital. To investigate this point, we have included an indicator for writing abilities (column 2), and both speaking and writing variables (column 3). The eßect of writing pro $^{-}$ciency (unconditional on ${ }^{\circ}$ uency) is slightly higher. When including both indicator variables, we ${ }^{-}$nd that writing abilities are associated with a 14 percent increase in employment probabilities, while speaking ability alone increases this probability by only 4 percentage points. The latter eßect is not signi ${ }^{-}$cant. This suggests that literacy in the dominant majority language, in addition to ${ }^{\circ}$ uency, is important to obtain a job.

\subsection{Earnings}

We now turn to analysing the eßect of language on earnings. B oth samples do not provide information on the number of hours worked per week. We consider here only individuals who are working full-time.

In the FWLS, the dependent variable is the natural logarithm of gross (before tax) 
weekly earnings. The earnings variable in the FNSEM is gross weekly earnings, which is reported in categorical form (16 categories). In both samples there is a considerable percentage of working individuals who do not report their earnings ( $28 \%$ in the F NSEM and $45 \%$ in the FWLS).

To check the extent to which attrition is non-random, we compare the means of the language variables, origin dummies, and the educational variables for individuals who do, and who do not report earnings. Results are presented in table A3. We also report the t-statistics for testing whether the means of the variables are signi ${ }^{-}$cantly di ßerent. In some cases, we reject the null hypothesis of equal means, but there seems to be no systematic pattern of attrition across the two data sets.

Our - nal sample sizes are 259 individuals for the FWLS data, and 967 individuals for the FNSEM data. Results of straightforward log wage regressions are presented in Table 6, where we use the least squares estimator for the F W LS, and a grouped regression model for the FNSEM (where the boundaries are transformed by taking logs).

As regressors, we include demographic and human capital characteristics, dummies for English pro ${ }^{-}$ciency, and dummies for ethnic background. Coe \pm cient estimates on most variables are roughly similar for the two data sets. M ales have a signi ${ }^{-}$cant earnings advantage, compared to females. Having a degree increases earnings by about 78 (FW LS) or 75 (F NSE M) percent, compared to holding no quali ${ }^{-}$cation. Vocational training alone increases earnings by about 16 (FWLS) or 22 (F NSE M) percent.

In the last column, we use the more detailed educational information in the F NSEM, 
and decompose educational attainments into overseas and UK quali ${ }^{-}$cations. We ${ }^{-}$nd that the coe \pm cients on UK quali ${ }^{-}$cations are larger than overseas ones, and the di ßerences are signi ${ }^{-}$cant for degree and Alevels. An overseas degree still increases earnings by $44 \%$, compared to those with no quali ${ }^{-}$cation; however, returns to a degree obtained in the UK are about 73\% higher. A slightly lower di ßerence exists for respondents with low Alevels (about 27\%).

The coe \pm cients on the ethnicity dummies indicate large wage di ßerences between ethnic groups. Like in the language and employment equations, Bangladeshis are the most disadvantaged group. Conditional on education, age and years of residence, wages are 54 percent lower than those of the most successful group, the Chinese (F NSEM). In both data sets, Indians and Caribbeans are receiving wages which are more than $30 \%$ higher than B angladeshi wages; also, Pakistani wages are about 20\% higher. 
Table 6: Earnings R egressions

\begin{tabular}{|c|c|c|c|c|c|c|c|c|c|c|}
\hline & \multicolumn{6}{|c|}{ FW LS } & \multirow{2}{*}{\multicolumn{4}{|c|}{$\begin{array}{l}\text { F N SEM } \\
\text { Speaking }\end{array}$}} \\
\hline \multirow[t]{3}{*}{ Variable } & \multicolumn{2}{|c|}{1} & \multicolumn{2}{|c|}{2} & \multirow{2}{*}{\multicolumn{2}{|c|}{3}} & & & & \\
\hline & & & & & & & \multicolumn{2}{|c|}{ All Quali ${ }^{-}$cations } & \multicolumn{2}{|c|}{ UK/nonUK Q } \\
\hline & Coe $\AA$ & t-ratio & Coe $\AA$ & t-ratio & Coe $\AA$ & t-ratio & $\mathrm{Coe} \circledast$ & t-ratio & Coe $\AA$ & t-ratio \\
\hline cons & 3.551 & 8.622 & 3.577 & 8.683 & 3.546 & 8.586 & 3.330 & 12.786 & 3.246 & 12.335 \\
\hline $\operatorname{sex}$ & 0.238 & 3.298 & 0.251 & 3.526 & 0.238 & 3.295 & 0.147 & 3.360 & 0.155 & 3.568 \\
\hline married & -0.010 & -0.121 & -0.008 & -0.097 & -0.008 & -0.095 & 0.161 & 2.886 & 0.146 & 2.620 \\
\hline degree & 0.786 & 7.505 & 0.788 & 7.428 & 0.781 & 7.350 & 0.702 & 13.146 & \{ & \{ \\
\hline Alevtea & 0.206 & 2.279 & 0.202 & 2.175 & 0.201 & 2.166 & 0.433 & 7.674 & \{ & \{ \\
\hline OlevCSE & 0.169 & 1.856 & 0.172 & 1.878 & 0.166 & 1.809 & 0.228 & 4.766 & \{ & \{ \\
\hline E degree & \{ & \{ & \{ & \{ & \{ & \{ & \{ & \{ & 0.729 & 11.786 \\
\hline EAlevtea & \{ & \{ & \{ & \{ & \{ & \{ & \{ & \{ & 0.418 & 7.031 \\
\hline EOlevCSE & \{ & \{ & \{ & \{ & \{ & \{ & \{ & \{ & 0.233 & 4.229 \\
\hline F degree & \{ & \{ & \{ & \{ & \{ & \{ & \{ & \{ & 0.437 & 6.093 \\
\hline FA levtea & \{ & \{ & \{ & \{ & \{ & \{ & \{ & \{ & 0.155 & 1.809 \\
\hline FOlevCSE & \{ & \{ & \{ & \{ & \{ & \{ & \{ & \{ & 0.136 & 2.488 \\
\hline age & 0.038 & 1.639 & 0.036 & 1.524 & 0.038 & 1.614 & 0.029 & 2.141 & 0.036 & 2.565 \\
\hline agesq & -0.045 & -1.550 & -0.042 & -1.441 & -0.044 & -1.522 & -0.035 & -2.108 & -0.040 & -2.410 \\
\hline yearst & 0.026 & 1.749 & 0.030 & 2.085 & 0.027 & 1.767 & 0.038 & 4.607 & 0.033 & 3.913 \\
\hline yearst $^{2}$ & -0.050 & -1.403 & -0.035 & -1.640 & -0.050 & -1.419 & -0.061 & -2.836 & -0.056 & -2.613 \\
\hline black & 0.302 & 2.285 & 0.327 & 2.504 & 0.301 & 2.271 & 0.479 & 5.840 & 0.480 & 5.817 \\
\hline afroas & 0.081 & 0.647 & 0.109 & 0.882 & 0.083 & 0.660 & 0.358 & 4.972 & 0.369 & 5.115 \\
\hline indian & 0.311 & 2.735 & 0.329 & 2.928 & 0.310 & 2.728 & 0.310 & 4.215 & 0.359 & 4.937 \\
\hline pakista & 0.239 & 2.015 & 0.251 & 2.126 & 0.239 & 2.012 & 0.186 & 2.399 & 0.222 & 2.889 \\
\hline Chinese & \{ & \{ & \{ & \{ & \{ & \{ & 0.562 & 6.232 & 0.527 & 5.787 \\
\hline speak & 0.204 & 1.774 & \{ & \{ & 0.171 & 1.062 & 0.162 & 2.706 & 0.170 & 2.850 \\
\hline write & \{ & & 0.149 & 1.444 & 0.040 & 0.282 & \{ & \{ & \{ & \{ \\
\hline \multirow[t]{2}{*}{ No. of Obs. } & \multicolumn{2}{|c|}{254} & \multicolumn{2}{|c|}{254} & \multicolumn{2}{|c|}{254} & \multicolumn{2}{|c|}{964} & \multicolumn{2}{|c|}{964} \\
\hline & & & & & & & & & & \\
\hline
\end{tabular}

In both data sets, we ${ }^{-}$nd large and signi- cant coe \pm cients on the English ${ }^{\circ}$ uency variables. The point estimates in the F NSEM and FW LS are quite similar, and indicate that English language pro- ciency is associated with 16 percent (F NSEM) or 20 percent (FW LS) higher wages. Interestingly, and di ßerent from the employment equation, ${ }^{\circ}$ uency seems to be more important for wages than literacy, as is indicated by the results both in columns 2 and 3. 


\subsection{Earnings A ssimilation and Language}

Both the FNSEM and the FWLS contain comparison samples on native born non-white minorities, and on white natives. Not much is known about the performance of ethnic minority immigrants, relative to native born minorities, and to white natives. Earlier work by Blackaby et al. (1994) suggests that black minorities in the UK are disadvantaged, compared to the white majority population. B ell (1997) adds to this evidence by breaking up the black minority into foreign-born and native-born individuals. He shows that the foreign-born have a substantial wage disadvantage, compared to black natives.

Using the samples on white and ethnic minority natives in the F NSE M and the FW LS, we use simple regression analysis to compare earnings paths of minority immigrants to native born minorities, and to white native born individuals.

Results of basic speci- cations are reported for all three groups in tables A 4 and A5. For the FNSEM, we run regressions including, and excluding minority dummies. Results in column 3 in table A 4 are identical to results in Table 6.

As for minority immigrants, there are di ®erences between ethnic groups also in the native born sample. The coe \pm cients on the ethnicity dummies are not estimated with great precision, due to the small sample size, but the estimates indicate a similar pattern to the immigrant sample. A gain, the Chinese seem to be most successful; furthermore, the Bangladeshis seem to be the most disadvantaged group. We have also included ethnicity dummies in the FWLS native minority sample (results not reported). Since the sample is very small, coe \pm cients are not signi ${ }^{-}$cant, but they are all positive (again, we exclude 
the Bangladeshi group).

To illustrate wage paths and wage assimilation of immigrants to the native born, we plot log weekly earnings against age in the labour market, where we assume for immigrants that the age at entry is 20 years (which is close to the sample average for both samples). Graphical illustrations are based on results in columns 1, 2, and 4, of table A4, and on results in table $A 5$, where no origin dummies are included. We compute entry wages for each group as the sum of the regression coe \pm cients, weighted by the respective sample means, and setting the language dummy equal to zero, or to one for immigrants. Accordingly, wage paths for immigrants represent an average of the paths of individuals of di ßerent ethnic groups (according to the sample data), who do (not) speak the English language well. Figures (1) and (2) display the age-earnings pro-les.

Figure 1: Log Weekly Earnings - A ge Pro``les, F NSEM

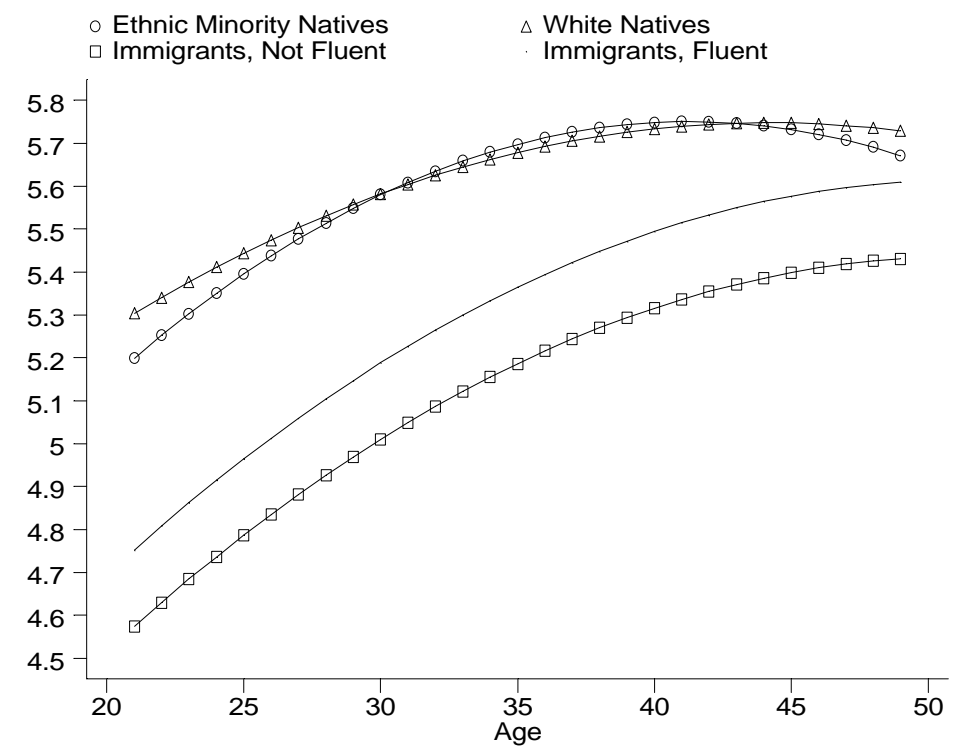

Log wage pro`les for white natives and minority natives are remarkably similar for 
Figure 2: Log Weekly Earnings - A ge Pro- les, FWLS

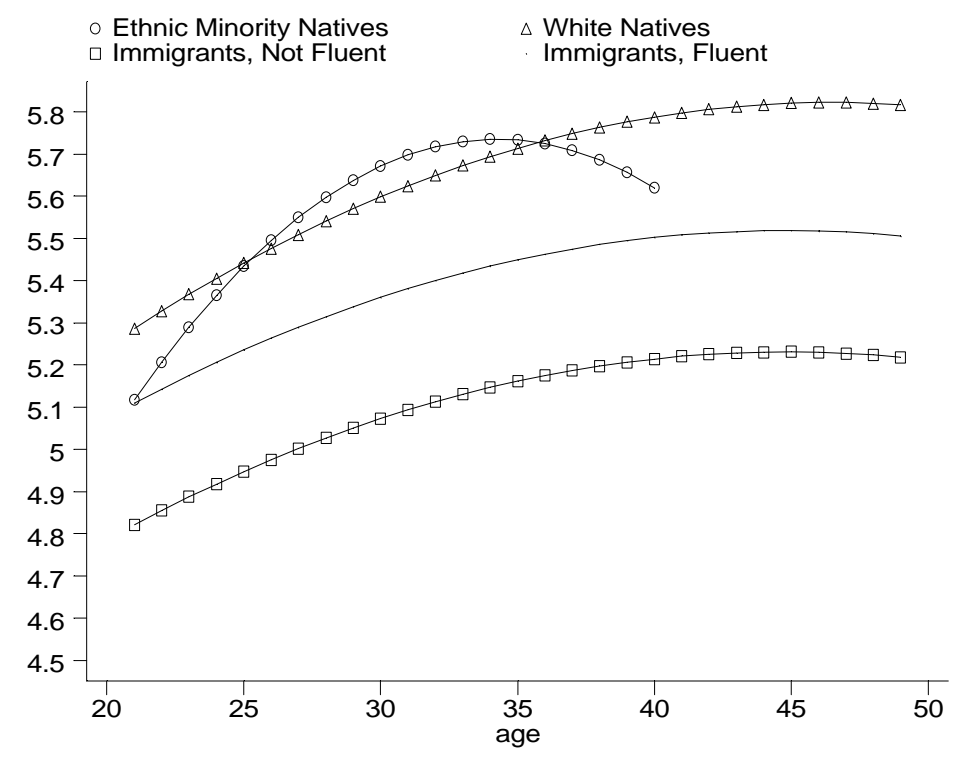

both samples, with white native pro ${ }^{-}$les being almost identical. ${ }^{6}$ Entry level wages for minorities are slightly lower than those for whites.

For the F NSEM, the entry level wage di ßerence for minority immigrants who are not ${ }^{\circ}$ uent in English is quite dramatic. The di ßerence in log entry wages is about 0.74 between immigrants and white natives, and 0.62 between immigrants and native minorities. The gap is closing, but it never disappears. At the average age in our sample (which is 42 years), the log di ßerence is still 0.39 (which corresponds to a 46 percent wage gap). If we compute the wage gap between speci ${ }^{-} \mathrm{c}$ ethnic groups and white natives at the average sample age, we obtain a more diverse picture. For instance, while the log wage gap between a (non- ${ }^{\circ}$ uent) $B$ angladeshi immigrant and a native is about 0.7 , it is only 0.14

\footnotetext{
${ }^{6}$ For the FWLS, we plot the minority natives only up to age 40. After that age there is hardly any data support.
} 
between a native white and a Chinese immigrant, or 0.22 between a native white and an Indian immigrant. Ethnic origin plays a major role in predicting disadvantages of immigrant minorities.

For immigrants who are ${ }^{\circ}$ uent in English, the wage disadvantage reduces quite considerably. For some ethnic groups, it disappears completely. For Chinese immigrants who are ${ }^{\circ}$ uent in English, the wage gap is positive, and it nearly disappears for Indians.

For the FWLS, the initial log earnings gap between white natives, and non- ${ }^{\circ}$ uent minority immigrants is about 0.46 , which is slightly lower, but still considerable. The gap seems to widen slightly over the immigrant's migration history. The larger earning gap in the FNSEM may be related to the sample composition. Remember that computations are for the average for the di ßerent ethnic groups, according to the ethnicity composition in our data. Since Bangladeshis (the most disadvantaged group) are oversampled in the FNSEM, the estimates may indeed slightly overstate the wage disadvantage of the average ethnic minority immigrant. Also, individuals in the FNSEM are on average slightly older than those in the FW LS. Still, the results suggest that minority immigrants are, on average, heavily disadvantaged, not only at entry to the labour market, but over their entire migration history. On the other side, minority native born individuals do surprisingly well. This underlines the importance of distinguishing between native and foreign born minorities when analysing their economic assimilation.

As for the FNSEM, the wage gap closes quite considerably for immigrants who are ${ }^{\circ}$ uent in English. For the FWLS, this reduction amounts to half of the initial wage gap. 
Based on these estimates, some simple back of the envelope calculations, based on FNSEM results, suggest that an immigrant, who arrives at age 20 , and who does not acquire ${ }^{\circ}$ uency in English over the ${ }^{-}$rst ten years of his/her migration history, looses about $\$ 10,000$, compared to an immigrant who arrives with language ${ }^{\circ}$ uency. This is a very considerable amount, given that the earnings accumulated by an average immigrant over that period is $\$ 68,000$. Similar calculations for the FW LS suggest an earnings loss of even $\$ 21,000$, with the average earnings over the 10 years period being equal to $\$ 86,000$.

\subsection{M easurement error and unobserved ability}

The results suggest that language is a most important determinant of labour market success, and that the earnings disadvantage of minority immigrants relative to native born individuals is largely reduced if the individual is pro $^{-}$cient in the English language. The estimated coe \pm cients in outcome equations of the sort estimated above may be seriously biased however due to unobserved heterogeneity and measurement error. In this section, we address this problem.

To address the bias due to measurement error, we use the language in which the interview has been performed as an instrument for the assessed language pro ${ }^{-}$ciency of the respondent. This information is available in the F NSE M. In all areas with a minority density above $0: 5 \%$ (which includes $97 \%$ of the sample individuals), there was an initial screening interview with the interviewee. In the case of poor ${ }^{\circ}$ uency, the interviewers were chosen to be ${ }^{\circ}$ uent in the language of the respondents. During the interview, interviewers 
decided about the extent to which English could be used in the interview, and we have information as to whether the interview was held wholly in English, partly in English, or wholly in the individual's mother tongue. We use this information as instrument for the assessed language ${ }^{0}$ uency of the individual. ${ }^{7}$

This variable does not eliminate the bias due to unobserved heterogeneity, however. Our estimation strategy for the unobserved heterogeneity component is a type of matching estimator, as explained above. We add partner and family variables to the main equation. If these variables explain some of the variation in the unobserved error component which is correlated with language pro- ciency, this estimator reduces (or eliminates) the bias due to unobserved heterogeneity.

In Table 7, we display results for the employment and earnings equations. We report marginal eßects, evaluated at sample means. The ${ }^{-}$rst column corresponds to the simple estimates in Tables 5 and 6 . Column 2 reports IV estimates, where we use interview language as an instrument. This eliminates the bias due to measurement error, but not the bias due to unobserved heterogeneity. We ${ }^{-}$rst discuss results for the employment equation. We estimate the employment equation as a bivariate probit model, using maximum likelihood. Marginal eßects increase from 17 percent to 22 percent, and the correlation coe \pm cient is negative and signi ${ }^{-}$cant, indicating a downward bias due to measurement error.

\footnotetext{
${ }^{7}$ Since ${ }^{\circ}$ uency in the FNSEM is also interviewer assessed, measurement error in the two language variables may be correlated. Should this be the case, our estimation strategy does only reduce, but not entirely eliminate the bias. Therefore, the estimates we obtain are a lower bound.
} 
Adding partner variables reduces our sample to married couples, and we report in column 3 the marginal eRects for this restricted sample. For completeness, we also report the corresponding coe \pm cient for the F W LS sample. B oth are lower than the coe \pm cient in the overall sample. Column 4 reports results without conditioning on family background, but using the information on interview language as instruments to eliminate the measurement error bias. The coe \pm cient increases by about 4 percentage points, as compared to results in column 3. Finally, column 5 reports results when we include family background characteristics, and use IV estimation. Inclusion of the family variables reduces the coe \pm cient by 2 percentage points, but the estimate is still larger than that of the simple regression model. The correlation coe \pm cient is negative in both regressions. 
Table 9: Language and Employment Probabilities

\begin{tabular}{|c|c|c|c|c|c|c|c|c|}
\hline & \multicolumn{3}{|c|}{ All } & \multicolumn{5}{|c|}{ M arried Sample } \\
\hline Variable & 1 & 2 & & 3 & 2 & & & \\
\hline \multicolumn{9}{|c|}{ Language and Employment Probabilities } \\
\hline & M.E. t-ratio & M.E. & t-ratio & t-ratio & M.E. & t-ratio & M.E. & t-ratio \\
\hline \multicolumn{9}{|l|}{ FNSEM } \\
\hline Speak & $0.172 \quad 5.99$ & 0.218 & 6.27 & 0.136 & 0.171 & 4.64 & 0.153 & 3.93 \\
\hline $1 / 2$ & & -0.425 & -2.35 & & -0.330 & -1.78 & -0.320 & -1.66 \\
\hline N. Obs. & 2092 & 20 & 92 & 1653 & 16 & & & \\
\hline \multicolumn{9}{|l|}{ FWLS } \\
\hline Speak & $0.222 \quad 4.24$ & & & $0.186 \quad 3.34$ & & & & \\
\hline N. Obs. & 849 & & & 643 & & & & \\
\hline \multicolumn{9}{|c|}{ Language and Earnings } \\
\hline & Coe $\AA$. t-ratio & Coe $\AA$ & t-ratio & Coe $\AA$, t-ratio & Coe $\AA$ & t-ratio & $\mathrm{Coe} \AA$. & t-ratio \\
\hline \multicolumn{9}{|l|}{ FNSEM } \\
\hline Speak & $0.162 \quad 2.706$ & 0.223 & 2.55 & 3.175 & 0.271 & 2.857 & 0.255 & 2.64 \\
\hline $1 / 2$ & & -0.030 & 0.12 & & -0.084 & 0.54 & -0.06 & 0.41 \\
\hline N. Obs. & 964 & 9 & 54 & 777 & 77 & & & \\
\hline \multicolumn{9}{|l|}{ FWLS } \\
\hline Speak & $0.204 \quad 1.774$ & & & $0.229 \quad 1.968$ & & & & \\
\hline N. Obs. & 259 & & & 257 & & & & \\
\hline \multicolumn{9}{|c|}{$\begin{array}{l}\text { 1: Grouped Regression. 2: Grouped Regression/ Probit, using interview language as instruments. } \\
\text { 3: Grouped Regression. }\end{array}$} \\
\hline
\end{tabular}

In lower panel of table 9, we report the corresponding results for the earnings equation. We estimate the model using maximum likelihood, using a grouped regression/ probit mixture. Instrumenting language increases the coe \pm cient by about 6 percentage points, indicating a strong downward bias due to measurement error in straightforward estimations. Other than for the employment equation, the language coe \pm cient increases slightly when considering married individuals only (column 3). Column 4 shows that instrumenting language for measurement error leads, as before, to a substantial increase in the coe \pm cient for this subsample (by about 7 percentage points). In column 5 we add partner 
variables to account for unobserved heterogeneity. A s in the employment estimation, the coe \pm cient reduces slightly in size, but is still larger than the coe \pm cient in straightforward regressions.

These results suggest that measurement error leads to quite a substantial downward bias in the e®ect of language on labour market outcomes. They indicate that language is more important than straightforward regressions suggest, and that the simple calculations we have performed in the previous section on the earnings loss and employment probabilities due to a lack of language ${ }^{\circ}$ uency may be underestimates, rather than overestimates.

\section{Discussion and Conclusion}

Based on two recent UK surveys, which provide su \pm ciently large samples to study ethnic minority immigrants, we analyse the determinants of English language ${ }^{\circ}$ uency for ethnic minority migrants in the UK, the e®ect of language on labour market outcomes, and the contribution of language to reduce the earnings gap between immigrants, and native born individuals.

We ${ }^{-}$nd that in simple regressions, language pro $^{-}$ciency is strongly associated with higher employment probabilities, and with higher earnings. W hen we compare earnings of minority immigrants with those of white and minority natives, our data indicates a substantial disadvantage for the average immigrant, compared to white natives. The same patterns of ethnic di ßerences in earnings can be observed between ethnic minority immigrants, and ethnic minority natives. The earnings disadvantage does not disappear 
over time. There are large earnings di ßerences between individuals who belong to di ßerent minority communities - Chinese immigrants, for instance, have about 50 percent higher earnings than Bangladeshi immigrants. The earnings gap is therefore much smaller (and even reverses) for some minority immigrants, while it is larger for others. Language pro $^{-}$ciency is an important factor in reducing these earnings di ßerences.

Language eßects may be under- or overestimated in straightforward regressions, due to unobserved heterogeneity and measurement error. We address both these issues. To reduce the bias due to unobserved heterogeneity components, we use a simple matching approach. To address the bias due to measurement error, we use information about the interview language as an instrument of the individual's language potential. Our results indicate that measurement error leads to a downward bias in language estimates for both outcomes. Straightforward regressions seem to underestimate this eßect by about 6 percentage points.

Table 10: Language and Earnings, di ßerent countries

\begin{tabular}{l|ccccccc}
\hline \hline & UK FNSEM & UK FWLS & Germany $^{1}$ & United States $^{2}$ & Canada $^{2}$ & A ustralia $^{2}$ & |srael $^{2}$ \\
\hline OLS & 0.209 & 0.229 & 0.040 & 0.169 & 0.122 & 0.083 & 0.11 \\
StdE & $(0.066)$ & $(0.116)$ & $(0.011)$ & $(0.013)$ & $(0.050)$ & $(0.017)$ & $(0.009)$ \\
IV (M.E.) & \{ & 0.271 & 0.129 & \{ & \{ & \{ & \{ \\
StdE & \{ & $(0.090)$ & $(0.017)$ & \{ & \{ & \{ & \{ \\
IV, Matching & \{ & 0.255 & 0.097 & \{ & \{ & \{ & \{ \\
StdE & \{ & $(0.112)$ & $(0.064)$ & \{ & \{ & \{ & \{ \\
\hline Standard errors in brackets \\
×: Married Subsample \\
1: Dustmann and van Soest (1999). 2: Chiswick and Miller (1995). \\
?
\end{tabular}

How do results on the eRects of language on earnings compare to those of other countries? In table 10, we display estimates obtained for Germany, the US, Canada, A ustralia, 
and Israel. The numbers reveal that the association between language and earnings is largest for the UK, followed by the US and Canada. Much smaller eßects are found for Germany, A ustralia, and Israel. A ccordingly, language is most important in the UK labour market. A reason for the relatively larger estimates, compared to Germany and Israel, may be that English is a more dominant language than German or Hebrew; thus, coming from a minority population, it may be possible to communicate with other minorities, or majority individuals, in a third language (which will be English in most cases). However, a bad ${ }^{\circ}$ uency in English, if English is the majority language, is likely to have more serious consequences. Not only does it hinder communication with majority individuals, but also with other minorities (or even with minority individuals of the same ethnic origin who speak a di ßerent language). The relatively large coe \pm cients found for the US are in line with this interpretation.

There is only one study (for Germany) which instruments for measurement error in the language variables. Instrumenting leads to quite a dramatic increase in the coe \pm cient, but estimates are still much lower than those for the UK. In both studies, coe \pm cient estimates reduce slightly in size when matching on partner variables.

We may conclude that language pro- ciency is an important factor for economic success of immigrants in the UK, and the earnings losses immigrants experience due to a lack of language ${ }^{\circ}$ uency are substantial. Language seems to be more signi ${ }^{-}$cant in a Recting earnings of UK immigrants than those of immigrants to other countries. A s a consequence, it may be worthwhile to implement schooling centers which support immigrants in their 
acquisition of the English language at an early stage of their migration history. Given the substantial earnings disadvantages immigrants experience due to a lack of English ${ }^{\circ}$ uency, there is clearly an incentive for the migrants to bear part of the costs of language education. 


\section{R eferences}

2 B ell, B.D. (1997): "The Performance of Immigrants in the United Kingdom: Evidence from the GHS", The Economic J ournal, 107, pp. 333-344.

2 Blackaby, D.H., Clark, K., Leslie, D.G., Murphy, P.D. (1994): "Black-white male earnings and employment prospects in the 1970s and 1980s Evidence for Britain", E conomics Letters, 46, pp. 273-279.

2 Blackaby, D.H., Drinkwater, S., Leslie, D.G., Murphy, P.D. (1997): "A Picture of Male and Female Unemployment A mong Britain's Ethnic M inorities", Scottish J ournal of Political Economy, 44(2), pp. 182-197.

2 B orjas (1985), A ssimilation, Changes in Cohort Quality, and the Earnings of Immigrants, J ournal of Labour Economics, 3, 463-489.

2 B orjas, G .J. (1987): \Self-Selection and the Earnings of Immigrants," American E conomic Review, 77, 531-553

2 B orjas, G.J . (1994):"The E conomics of Immigration", J ournal of E conomic Literature, 32, pp. 1667-1717.

${ }^{2}$ C hisw ick, B , R . (1978): \T heE Rect of A mericanization on the E arnings of ForeignB orn Men," J ournal of Political E conomy, 86, 897 - 921.

2 Chiswick, B.R. (1980): "The Earnings of White and Coloured M ale Immigrants in B ritain", E conomica, 47, pp. 81-87. 
2 Chiswick, B.R. (1991): "Speaking, Reading, and Earnings among Low-skilled Immigrants", J ournal of Labor Economics, 9, pp. 149-170.

2 Chiswick, B.R. (1994): "Language Choice A mong Immigrants in a Multi-Lingual Destination", J ournal of Population Economics, 7, pp. 119-131.

2 Chiswick, B.R., Miller, P.W. (1995): "The Endogeneity between Language and Earnings: International A nalyses", J ournal of Labor E conomics, 13, pp. 246-288.

2 Chiswick, B.R., Cohen, Y., Zach, T. (1997): "T he Labor Market Status of Immigrants: E Rects of the Unemployment Rate at Arrival and Duration of R esidence", Industrial and Labor Relations Review, 50(2), pp. 289-303.

2 Dearden, L. (1999): "Quali" cations and Earnings in Britain: How reliable are Conventional OLS estimates of the Returns to Education?", IFS working paper No. W 99/ 7.

2 Dustmann, C. (1994): "Speaking F luency, writing 'uency and earnings of migrants", J ournal of Population Economics, 7, pp. 133-156.

2 Dustmann, C. van Soest, A. (1998): " Language and the Earnings of Immigrants", Centre for Economic Policy Research Discussion Paper No. 2012.

2 Dustmann, C., Fabbri, F., and Preston, I. (2000): " The Causal E ßect of Ethnic Concentration on Language ", mimeo, University College London. 
2 Eckstein, Z. and Y. Weiss (1999): "The Integration of Immigrants from the Former Soviet Union in the Israeli Labour Market", mimeo, Tel A viv University.

2 Green, A.E., Owen, D.W. (1995): "Ethnic Minority Groups in Regional and Local Labour Markets in Britain: A Review of Data Sources and Associated Issues", Regional Studies, 29(8), pp. 729-735.

2 Hatton, T.J., and S. W heatley Price (1999), " Migration, Migrants and Policy in the United Kingdom", IZA discussion paper No. 81.

2 Lazear, E.P. (1995): "Culture and Language", NBER working paper No. 5249.

2 Modood, T., Berthoud, R. (1997): Ethnic Minorities in Britain, Policy Studies Institute, London.

2 Nickell, S.J . (1980): "A Picture of Male Unemployment In Britain", Economic J ournal, 90, pp. 776-794.

2 Rivera-Batiz, F. L. (1990): "English language pro- ciency and the economic progress of immigrants", E conomics Letters, 34, pp. 295-300.

2 Rosenbaum, P., Rubin, D.B. (1983): "The central role of the propensity score in observational studies for causal eßects", Biometrika, 70, pp. 41-55.

2 Shields, M.A., Wheatley Price, S. (1998): "The Earnings of Male Immigrants in England: Evidence From the Quarterly LFS", Applied Economics, forthcoming. 
2 Shields, M.A., Wheatley Price, S. (1999): " The English Language F luency and Occupational Success of Ethnic M inority Immigrant M en Living in English M etropolitan A reas", University of Leicester Discussion Paper.

2 Sly, F. (1995):"Ethnic groups and the labour market", E mployment Gazette, May, pp. $147-158$.

2 Smith, P. and G. Prior (1996), "The Fourth National Survey of Ethnic M inorities: Technical Report", Social and Community Planning Research.

2 Stewart, M.B. (1983): "On Least Squares Estimation when the Dependent Variable is Grouped", Review of Economic Studies 50:737-753.

2 Wheatley Price, S. (1997): "The Employment A djustment of Male Immigrants to the English Labour M arket", mimeo, University of She eld. 


\section{A ppendix: Tables}

Table A 1: Language Information

\begin{tabular}{|c|c|c|c|c|c|c|c|}
\hline & All groups & Caribbean & Indian & A froasian & Pakistani & Bangladeshi & Chinese \\
\hline & \multicolumn{7}{|c|}{ English as 1st language, FWLS } \\
\hline Yes & 26.92 & 91.41 & 27.46 & 28.33 & 10.89 & 5.74 & - \\
\hline \multirow[t]{2}{*}{ No } & 73.08 & 8.59 & 72.54 & 71.67 & 89.11 & 94.26 & - \\
\hline & \multicolumn{7}{|c|}{ Speaking, FW LS } \\
\hline Very well & 37.81 & 54.55 & 50.44 & 64.77 & 38.16 & 25.93 & - \\
\hline Quite well & 23.12 & 13.64 & 27.43 & 27.27 & 26.05 & 18.46 & - \\
\hline Not well & 20.12 & 18.18 & 18.14 & 5.68 & 21.32 & 22.82 & - \\
\hline Hardly & 11.69 & 13.64 & 3.54 & 2.27 & 10 & 18.46 & - \\
\hline \multirow[t]{2}{*}{ Not at all } & 7.26 & \{ & 0.44 & \{ & 4.47 & 14.32 & - \\
\hline & \multicolumn{7}{|c|}{ Reading, FWLS } \\
\hline Very well & 34.64 & 40.91 & 48.67 & 61.36 & 33.16 & 24.07 & - \\
\hline Quite well & 21.12 & 18.18 & 23.89 & 26.14 & 21.58 & 18.67 & - \\
\hline Not well & 15.86 & 22.73 & 14.16 & 7.95 & 17.11 & 16.8 & - \\
\hline Hardly & 13.19 & 9.09 & 7.96 & 1.14 & 14.47 & 17.01 & - \\
\hline \multirow[t]{2}{*}{ Not at all } & 15.19 & 9.09 & 5.31 & 3.41 & 13.68 & 23.44 & - \\
\hline & \multicolumn{7}{|c|}{ Writing, FW LS } \\
\hline Very well & 32.39 & 40.91 & 45.13 & 56.82 & 29.47 & 23.86 & - \\
\hline Quite well & 19.2 & 18.18 & 21.68 & 23.86 & 20.79 & 15.98 & - \\
\hline Not well & 16.61 & 22.73 & 15.49 & 13.64 & 18.16 & 16.18 & - \\
\hline Hardly & 12.77 & 4.55 & 11.06 & 2.27 & 13.68 & 15.15 & - \\
\hline \multirow[t]{2}{*}{ Not at all } & 19.03 & 13.64 & 6.64 & 3.41 & 17.89 & 28.84 & - \\
\hline & \multicolumn{7}{|c|}{ Speaking, FNSE M } \\
\hline Fluent & 48.73 & 89.65 & 39.98 & 65.63 & 25.56 & 25.97 & 56.59 \\
\hline Fairly & 20.4 & 9.62 & 24.37 & 19.2 & 25.56 & 23.02 & 12.64 \\
\hline Slightly & 21.2 & \{ & 25.84 & 11.76 & 32 & 34.25 & 18.13 \\
\hline Not at all & 9.67 & \{ & 9.81 & 3.41 & 16.88 & 16.76 & 12.64 \\
\hline
\end{tabular}


Table A 2: A ge and Time Patterns

\begin{tabular}{l|rrrrrr}
\hline \hline Ethnicity & \multicolumn{2}{|c}{ A ge M igration } & \multicolumn{2}{c}{ Year } & \multicolumn{2}{c}{ A ge } \\
\hline & FW LS & F NSE M & FW LS & F NSEM & FW LS & F NSE M \\
\hline Carib & 19.460 & 20.379 & 1964.2 & 63.435 & 49.755 & 50.927 \\
& 8.840 & 10.186 & 7.968 & 7.772 & 12.199 & 13.933 \\
Indian & 18.971 & 23.892 & 1973.2 & 72.431 & 40.299 & 45.145 \\
& 10.235 & 13.535 & 9.750 & 9.515 & 11.004 & 14.384 \\
AfroA sia & 17.813 & 20.662 & 1974.1 & 73.828 & 37.976 & 40.735 \\
& 10.320 & 12.702 & 7.035 & 7.221 & 10.393 & 13.026 \\
Pakista & 18.167 & 20.424 & 1976.4 & 74.207 & 35.870 & 39.672 \\
& 9.374 & 11.275 & 9.634 & 9.677 & 11.953 & 13.738 \\
Bangla & 18.676 & 20.579 & 1979.6 & 77.695 & 33.266 & 36.645 \\
& 9.374 & 10.545 & 9.046 & 9.637 & 13.985 & 14.156 \\
Chinese & - & 22.088 & - & 76.35 & - & 39.641 \\
& - & 11.860 & - & 8.670 & - & 12.532 \\
\hline All & 18.663 & 21.418 & 1974.7 & 72.414 & 38.308 & 42.707 \\
& 10.084 & 11.918 & 1.402 & 9.944 & 13.587 & 14.572 \\
\hline \hline
\end{tabular}

Table A 3: Attrition

\begin{tabular}{|c|c|c|c|c|c|c|c|c|c|c|}
\hline \multirow{3}{*}{ Variable } & \multicolumn{5}{|c|}{ FW LS } & \multicolumn{5}{|c|}{ F N SEM } \\
\hline & \multicolumn{2}{|c|}{ Missing } & \multicolumn{2}{|c|}{ Report E arnings } & \multirow{2}{*}{$\frac{\mathrm{Di} \mathbb{R}}{\text { t-value }}$} & \multicolumn{2}{|c|}{ Missing } & \multicolumn{2}{|c|}{ Report E arnings } & \multirow{2}{*}{$\frac{\mathrm{Di} \AA}{\text { t-value }}$} \\
\hline & M ean & StdD & M ean & StdD & & M ean & StdD & M ean & StdD & \\
\hline sex & 0.730 & 0.444 & 0.618 & 0.486 & 2.584 & 0.675 & 0.468 & 0.695 & 0.460 & -0.460 \\
\hline married & 0.802 & 0.398 & 0.767 & 0.423 & 0.914 & 0.870 & 0.336 & 0.837 & 0.368 & 1.006 \\
\hline nchild & 1.995 & 1.712 & 1.480 & 1.341 & 3.539 & 1.511 & 1.592 & 1.507 & 1.466 & 0.027 \\
\hline degree & 0.110 & 0.314 & 0.153 & 0.361 & -1.368 & 0.226 & 0.419 & 0.195 & 0.396 & 0.810 \\
\hline Alevtea & 0.144 & 0.352 & 0.212 & 0.409 & -1.920 & 0.164 & 0.371 & 0.157 & 0.364 & 0.203 \\
\hline OlevCSE & 0.278 & 0.449 & 0.208 & 0.407 & 1.738 & 0.249 & 0.433 & 0.262 & 0.440 & -0.318 \\
\hline age & 38.274 & 10.456 & 37.704 & 10.006 & 0.594 & 41.556 & 10.378 & 39.214 & 10.253 & 2.426 \\
\hline yearstay & 22.783 & 9.453 & 22.303 & 9.3220 & 0.546 & 23.349 & 8.246 & 21.780 & 9.045 & 1.947 \\
\hline black & 0.182 & 0.387 & 0.204 & 0.404 & -0.595 & 0.109 & 0.312 & 0.217 & 0.412 & -3.203 \\
\hline afroas & 0.129 & 0.336 & 0.145 & 0.353 & -0.497 & 0.219 & 0.414 & 0.242 & 0.428 & -0.585 \\
\hline indian & 0.264 & 0.442 & 0.338 & 0.474 & -1.732 & 0.408 & 0.492 & 0.227 & 0.419 & 4.202 \\
\hline pakista & 0.278 & 0.449 & 0.173 & 0.379 & 2.680 & 0.197 & 0.398 & 0.147 & 0.354 & 1.411 \\
\hline Chinese & \{ & \{ & \{ & \{ & & 0.024 & 0.156 & 0.073 & 0.260 & \\
\hline speak & 0.865 & 0.342 & 0.877 & 0.327 & -0.382 & 0.879 & 0.325 & 0.872 & 0.333 & 0.227 \\
\hline write & 0.793 & 0.405 & 0.850 & 0.357 & -1.586 & \{ & \{ & \{ & \{ & \\
\hline \multirow[t]{2}{*}{ No. of Obs. } & \multicolumn{2}{|c|}{208} & \multicolumn{2}{|c|}{254} & & \multicolumn{2}{|c|}{401} & \multicolumn{2}{|c|}{1012} & \\
\hline & \multicolumn{10}{|c|}{$\begin{array}{l}\text { Note: t-statistics computed as }\left(m_{1} \text { i } m_{2}\right)=s e_{1}^{2}+s e_{2}^{2} \text {, where } m_{i} \text {, se are means and standard } \\
\text { errors of the two sample values, respectively. }\end{array}$} \\
\hline
\end{tabular}


Table A 4: I mmigrants, W hites, N ative born M inorities, FNSEM

\begin{tabular}{|c|c|c|c|c|c|c|c|c|c|c|}
\hline \multirow[t]{2}{*}{ Variable } & \multicolumn{3}{|c|}{ W hite Natives } & \multicolumn{3}{|c|}{ Immigrants } & \multicolumn{4}{|c|}{ Native $B$ orn $M$ inorities } \\
\hline & Coe $\AA$ & t-ratio & Coeß & t-ratio & $\mathrm{Coe}{ }^{\circledR}$ & t-ratio & $\mathrm{Coe} \circledast$ & t-ratio & $\mathrm{Coe}{ }^{\circledR}$ & t-ratio \\
\hline cons & 3.616 & 20.068 & 3.348 & 12.384 & 3.330 & 12.786 & 3.165 & 7.389 & 3.706 & 7.724 \\
\hline sex & 0.287 & 9.080 & 0.056 & 1.315 & 0.147 & 3.360 & 0.090 & 1.701 & 0.090 & 1.740 \\
\hline age & 0.073 & 7.667 & 0.046 & 3.257 & 0.029 & 2.141 & 0.110 & 3.922 & 0.062 & 2.128 \\
\hline agesq/ 100 & -0.082 & -6.916 & -0.052 & -3.078 & -0.035 & -2.108 & -0.133 & -2.895 & -0.000 & -1.582 \\
\hline degree & 0.705 & 14.015 & 0.762 & 13.963 & 0.702 & 13.146 & 0.577 & 6.283 & 0.583 & 6.473 \\
\hline AlevTea & 0.433 & 9.549 & 0.476 & 8.193 & 0.433 & 7.674 & 0.318 & 3.680 & 0.244 & 2.876 \\
\hline voc & 0.189 & 4.621 & 0.258 & 5.198 & 0.228 & 4.766 & 0.186 & 2.550 & 0.112 & 1.546 \\
\hline married & 0.097 & 2.872 & 0.137 & 2.435 & 0.161 & 2.886 & 0.036 & 0.663 & 0.100 & 1.813 \\
\hline yearstay & \{ & \{ & 0.033 & 3.941 & 0.038 & 4.607 & \{ & \{ & \{ & \{ \\
\hline yearst2/ 100 & \{ & \{ & -0.041 & -1.928 & -0.061 & -2.836 & \{ & \{ & \{ & \{ \\
\hline indian & \{ & \{ & \{ & \{ & 0.479 & 5.840 & \{ & \{ & 0.191 & 0.818 \\
\hline afroas & \{ & \{ & \{ & \{ & 0.358 & 4.972 & \{ & \{ & 0.312 & 1.200 \\
\hline pakista & \{ & \{ & \{ & \{ & 0.310 & 4.215 & \{ & \{ & 0.084 & 0.353 \\
\hline carib & \{ & \{ & \{ & \{ & 0.186 & 2.399 & \{ & \{ & 0.443 & 1.886 \\
\hline chinese & \{ & \{ & \{ & \{ & 0.562 & 6.232 & \{ & \{ & 0.435 & 1.570 \\
\hline speak & \{ & \{ & 0.178 & 2.903 & 0.162 & 2.706 & \{ & \{ & \{ & \{ \\
\hline No. of Obs. & \multicolumn{2}{|c|}{921} & \multicolumn{2}{|c|}{964} & \multicolumn{2}{|c|}{964} & \multicolumn{2}{|c|}{322} & \multicolumn{2}{|c|}{322} \\
\hline
\end{tabular}

Table A 5: Immigrants, W hites, Native born M inorities, FW LS

\begin{tabular}{l|rrrrrr}
\hline \hline Variable & \multicolumn{2}{|c}{ W hite Natives } & \multicolumn{2}{c}{ Immigrants } & Native B orn M inorities \\
\hline & Coe ${ }^{\circledR}$ & t-ratio & Coe ${ }^{\circledR}$ & t-ratio & Coe ${ }^{\circledR}$ & t-ratio \\
\hline cons & 3.499 & 28.246 & 3.670 & 9.104 & 1.346 & 1.771 \\
sex & 0.250 & 11.505 & 0.208 & 3.066 & 0.242 & 2.680 \\
age & 0.076 & 11.673 & 0.787 & 7.776 & 0.240 & 4.724 \\
agesq/ 100 & -0.082 & -10.071 & 0.243 & 2.726 & -0.351 & -4.121 \\
degree & 0.719 & 18.899 & 0.152 & 1.707 & 0.439 & 2.354 \\
A levTea & 0.437 & 13.103 & 0.055 & 2.475 & 0.160 & 1.170 \\
voc & 0.278 & 8.556 & -0.065 & -2.291 & 0.176 & 1.278 \\
married & 0.073 & 3.138 & -0.094 & -1.167 & -0.042 & -0.402 \\
yearstay & \{ & \{ & 0.006 & 0.454 & \{ & \{ \\
yearst2/ 100 & \{ & \{ & -0.007 & -0.215 & \{ & \{ \\
speak & \{ & \{ & 0.288 & 2.697 & \{ & \{ \\
\hline No. of Obs. & \multicolumn{7}{|c}{2559} \\
\hline Excluded categories: no education quali cation. \\
\hline \hline
\end{tabular}




\section{IZA Discussion Papers}

No. Author(s)

51

A. Barrett

P. J. O'Connell

52 J. Mayer

R. T. Riphahn

53

J. Hartog

P. T. Pereira

J. A. C. Vieira

54 M. Lofstrom

55

L. Goerke

56

A. Lindbeck

D. J. Snower

57

I. N. Gang

K. F. Zimmermann

58

T. Bauer

K. F. Zimmermann

59

D. J. DeVoretz

S. A. Laryea

60

C. Belzil

J. Hansen

61

R. Winkelmann

62

A. Thalmaier

63

M. Ward

64

M. Ward

65

H. Lehmann

J. Wadsworth

A. Acquisti

66

E. J. Bird

H. Kayser

J. R. Frick

G. G. Wagner
Title

Area

Date

Does Training Generally Work?

5

$8 / 99$

The Returns to In-Company Training

Fertility Assimilation of Immigrants: Evidence

3

$8 / 99$

from Count Data Models

Inter-industry Wage Dispersion in Portugal: high

but falling

$8 / 99$

Labor Market Assimilation and the

$8 / 99$

Self-Employment Decision of Immigrant

Entrepreneurs

Value-added Tax versus Social Security

Contributions

Centralized Bargaining and Reorganized Work:

Are they compatible?

Is Child like Parent?

Educational Attainment and Ethnic Origin

9/99

Occupational Mobility of Ethnic Migrants

$9 / 99$

Canadian Immigration Experience:

Any Lessons for Europe?

Subjective Discount Rates, Intergenerational

Transfers and the Return to Schooling

Immigration: The New Zealand Experience

$10 / 99$

Bestimmungsgründe von Fehlzeiten: Welche

Rolle spielt die Arbeitslosigkeit?

1/2/3 9/99

6

$10 / 99$

Your Everyday, Average Academic

$10 / 99$

Salary and the Gender Salary Gap in the Academic Profession

Grime and Punishment: Job Insecurity and Wage 4

Arrears in the Russian Federation

$10 / 99$

The Immigrant Welfare Effect: Take-Up or

3

$10 / 99$ 

of Wage Differentials Transition Economies

\section{0 \\ J. C. van Ours}

J. Veenman
The Netherlands: Old Emigrants - Young Immigrant Country

Migration, Migrants and Policy in the United Kingdom

Privacy, time consistent optimal labor income taxation and education policy

Female Labour Supply, Flexibility of Working Hours, 1 and Job Mobility in the Netherlands

The Heterogeneity and Cyclical Sensitivity of 1 Unemployment: An Exploration of German Labor Market Flows 

Adversity

91 M. Lechner

Tenures that Shook the World: Worker Turnover in $\quad 4$ Russia, Poland and Britain

Identification and Estimation of Causal Effects of

An Evaluation of Public-Sector-Sponsored

Continuous Vocational Training Programs in East

N. Smith 
107 J. C. van Ours G. Ridder

J. Boone

J. C. van Ours

109 G. J. van den Berg

B. van der Klaauw

110 D. DeVoretz

C. Werner

111 V. Sorm

K. Terrell

L. Bellmann

T. Schank

113 R. Euwals

114 G. Brunello

A. Medio

115 A. Cigno

F. C. Rosati

116

C. Belzil

A. Haas

C. Klose

118 M. A. Shields

M. E. Ward

119 A. Lindbeck

D. J. Snower

120 P. T. Pereira

P. S. Martins

121 J. C. van Ours
Fast Track or Failure: A Study of the Completion

Rates of Graduate Students in Economics

Modeling Financial Incentives to Get Unemployed Back to Work

Combining Micro and Macro Unemployment

3

$1 / 00$

Duration Data

A Theory of Social Forces and Immigrant Second

1

$2 / 00$

Language Acquisition

Sectoral Restructuring and Labor Mobility:

A Comparative Look at the Czech Republic

Innovations, Wages and Demand for

5

$2 / 00$

Heterogeneous Labour: New Evidence from a

Matched Employer-Employee Data-Set

Do Mandatory Pensions Decrease Household

Savings? Evidence for the Netherlands

An Explanation of International Differences in

Education and Workplace Training

Why do Indian Children Work, and is it Bad for

3

$2 / 00$

Them?

Unemployment Insurance and Subsequent Job

3

$2 / 00$

Duration: Job Matching vs. Unobserved

Heterogeneity

IAB Employment Subsample 1975-1995.

Opportunities for Analysis Provided by the

Anonymised Subsample

Improving Nurse Retention in the British National

5

$2 / 00$

Health Service: The Impact of Job Satisfaction on Intentions to Quit

The Division of Labor and the Market for

Organizations

Does Education Reduce Wage Inequality?

5

Quantile Regressions Evidence from Fifteen

European Countries

Do Active Labor Market Policies Help Unemployed Workers to Find and Keep Regular Jobs? 
Rational Poverty or Poor Rationality? The Take-up of Social Assistance Benefits

125 F. Büchel

The Income Portfolio of Immigrants in Germany -

Effects of Ethnic Origin and Assimilation. Or:

J. R. Frick

126 J. Fersterer

R. Winter-Ebmer

Who Gains from Income Re-Distribution?

127 M. Karanassou

D. J. Snower

Smoking, Discount Rates, and Returns to

Education

Characteristics of Unemployment Dynamics: The

Chain Reaction Approach

128 O. Ashenfelter

D. Ashmore

O. Deschênes

Do Unemployment Insurance Recipients Actively

Seek Work? Evidence From Randomized Trials in

Four U.S. States

129 B. R. Chiswick

M. E. Hurst

C. Lucifora

The Employment, Unemployment and Unemployment Compensation Benefits of Immigrants

The Returns to Education in Italy: A New Look at the Evidence

Are Immigrants Favorably Self-Selected? An

134 A. D. Kugler

G. Saint-Paul

135 A. Barrett P. J. O'Connell

136 M. Bräuninger M. Pannenberg

Is There a Wage Premium for Returning Irish

Unemployment and Productivity Growth: An

Empirical Analysis within the Augmented Solow 
141 R. Hujer

M. Wellner

142

J. J. Dolado

F. Felgueroso

J. F. Jimeno

143 P. J. Luke

M. E. Schaffer

144 G. Saint-Paul

145 M.-S. Yun

146 T. K. Bauer

J. P. Haisken-DeNew

147 M. Belot

J. C. van Ours

148 L. Goerke

149 R. Lalive

J. C. van Ours

J. Zweimüller

150 J. DiNardo

K. F. Hallock

J.-St. Pischke

151 M. Ward

152 J. J. Dolado

F. Felgueroso

J. F. Jimeno

153 A. S. Kalwij

M. Gregory

154 Michael Gerfin Michael Lechner

155 J. Hansen

156 C. Dustmann

F. Fabbri
The Effects of Public Sector Sponsored Training on

Individual Employment Performance in East

Germany

Explaining Youth Labor Market Problems in Spain: 3

Crowding-Out, Institutions, or Technology Shifts?

Wage Determination in Russia: An Econometric

Investigation

Flexibility vs. Rigidity: Does Spain have the worst of 1 both Worlds?

Decomposition Analysis for a Binary Choice Model 7

$4 / 00$

Employer Learning and the Returns to Schooling

5

Does the Recent Success of Some OECD

Countries in Lowering their Unemployment Rates

Lie in the Clever Design of their Labour Market

Reforms?

Employment Effects of Labour Taxation in an Efficiency Wage Model with Alternative Budget

Constraints and Time Horizons

The Impact of Active Labor Market Programs and

Benefit Entitlement Rules on the Duration of Unemployment

Unions and the Labor Market for Managers

7

Gender, Salary and Promotion in the Academic Profession

The Role of the Minimum Wage in the Welfare 3

State: An Appraisal

Overtime Hours in Great Britain over the Period 3

1975-1999: A Panel Data Analysis

Microeconometric Evaluation of the Active Labour 6 Market Policy in Switzerland

The Duration of Immigrants' Unemployment Spells: $\quad 1 / 3 \quad 5 / 00$

Evidence from Sweden

Language Proficiency and Labour Market Per- 1

formance of Immigrants in the UK
$4 / 00$

$5 / 00$

$5 / 00$

$5 / 00$

$5 / 00$

$4 / 00$

$4 / 00$

$4 / 00$

$4 / 00$

$4 / 00$

$5 / 00$

$5 / 00$

$5 / 00$

$5 / 00$ 